\title{
High-power Low-frequency Ultrasound: a Review of Tissue Dissection and Ablation in Medicine and Surgery
}

\author{
Brendan O'Daly \\ Royal College of Surgeons in Ireland \\ Edmund Morris \\ Dublin City University \\ Graham Gavin \\ Technological University Dublin, graham.gavin@tudublin.ie
}

See next page for additional authors

Follow this and additional works at: https://arrow.tudublin.ie/engschmanart

Part of the Biomedical Engineering and Bioengineering Commons

\section{Recommended Citation \\ O'Daly, B., Morris, E., Gavin, G., O'Byrne, J., McGuinness, G.: High-power low-frequency ultrasound: A review of tissue dissection and ablation in medicine and surgery. Journal of Materials Processing Technology. Volume 200, Issues 1-3, Pages 38-58. 8 May 2008. doi:10.21427/8k5k-pg74}

This Article is brought to you for free and open access by the School of Manufacturing and Design Engineering at ARROW@TU Dublin. It has been accepted for inclusion in Articles by an authorized administrator of ARROW@TU Dublin. For more information, please contact arrow.admin@tudublin.ie, aisling.coyne@tudublin.ie, gerard.connolly@tudublin.ie. Funder: Enterprise Ireland

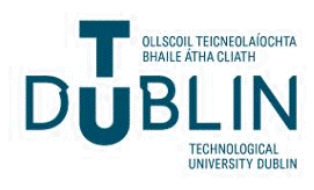


Authors

Brendan O'Daly, Edmund Morris, Graham Gavin, John O'Byrne, and Garrett McGuinness

This article is available at ARROW@TU Dublin: https://arrow.tudublin.ie/engschmanart/5 


\title{
High-power low-frequency ultrasound: A review of tissue dissection and ablation in medicine and surgery
}

\author{
Brendan J. O’Dalya,b, Edmund Morrisb, Graham P. Gavinc, \\ John M. O’Byrnea, Garrett B. McGuinnessb, $\square$
}

\begin{abstract}
a Department of Trauma and Orthopaedic Surgery, Royal College of Surgeons in Ireland, Cappagh National Orthopaedic Hospital, Dublin 11, Ireland

b Medical Ablation Technology Group, Materials Processing Research Centre, School of Mechanical and Manufacturing Engineering, Dublin City University, Dublin 9, Ireland

¿Department of Manufacturing Engineering, Dublin Institute of Technology, Dublin 1, Ireland
\end{abstract}

\begin{abstract}
High-power low-frequency ultrasound in the range $20-60 \mathrm{kHz}$ has wide ranging clinical applications in surgical and medical instruments for biological tissue cutting, ablation or fragmentation, and removal. Despite widespread clinical application and common device operating characteristics, there is an incomplete understanding of the mechanism of tissue failure, removal and damage. The relative contribution of cavitation, direct mechanical impact and thermal effects to each process for specific tissue types remains unclear. Different and distinct mechanisms and rates of tissue removal are observed for interaction with soft and hard tissue types. Device operating parameters known to affect the interaction include frequency, peak-peak tip amplitude, suction and application time. To date, there has been little analysis of the effect of variations in, and interactions of, these parameters on tissue removal and damage for individual biological tissue types. Potential controllable damage mechanisms occurring in tissues include alteration in global biomechanical properties, histomorphological changes, protein denaturation and tissue necrosis. This paper presents a critical review of the literature on the clinical application, mechanism of tissue interaction, removal and residual tissue damage. It describes known mechanisms for distinct tissue types.
\end{abstract}




\section{Introduction}

\subsection{Overview}

Ultrasonic medical and surgical devices operate in the high power low-frequency range $20-60 \mathrm{kHz}$ for biological tissue cutting, ablation or fragmentation, and removal. All such ultrasonic surgical systems use an ultrasonic frequency vibrating metal probe to achieve a desired effect (Fig. 1a-c).

These devices have gained widespread acceptance and use in surgical (orthopaedic, ophthalmic, general, plastic, oral maxillofacial, urological and neurosurgery) procedures for tissue dissection, fragmentation and ablation applications and offer promise in interventional cardiology procedures.

Clinical experience with ultrasonic instruments in each of these areas is extensive, yet the mechanism of tissue interaction is still widely debated and viewed differently in each surgical speciality. The tissue ablation and damage mechanism is poorly understood and mechanisms for damage minimisation have not been clearly defined. The literature reporting the mechanism of interaction is limited and frequently conflicting (Chan et al., 1986; Bond and Cimino, 1996; Beissner, 1980; Cimino and Bond, 1996). This incompleteness in understanding underpins the reticence of some clinicians to embrace this technology.

Ultrasonic surgery has generated renewed interest in low frequency, high-intensity vibratory energy. Distinct clinical effects are observed for a range of materially different tissues (lipid, viscera, soft tissues, dental and vascular plaques, ocular lens and bone). In simplest terms, it is thought that the vibrating ultrasonic tip is used to cut or shatter hard tissue or to cut and emulsify soft tissues (Bond and Cimino, 1996; Cimino and Bond, 1996;Wells, 1984). Parameters affecting cutting (Khambay and Walmsley, 2000a,b) and removal rate (Chan et al., 1986; Cimino and Bond, 1996; Stumpff et al., 1975), effect of dissipated ultrasonic energy and extent of residual tissue damage (Emam and Cuschieri, 2003; Koch et al., 2003) in individual tissues have been investigated experimentally.

Recent clinical studies have additionally highlighted the potentially deleterious thermal (Goldberg et al., 2005) and mechanical (Kim et al., 2006) effect of ultrasonic energy in residual tissue.

Given the many current and potential medical and surgical applications, the need for a better understanding, not alone of high-power low-frequency ultrasound technology, but of the important tissue-device interaction and damage mechanics is of paramount importance.

Medical ultrasound devices are ultrasonic devices used for diagnostic and therapeutic purposes in patients. Non-medical ultrasound devices are used for a variety of industrial applications such as ultrasonic welding, cutting, drilling and 
cleaning. In either, the ultrasound wave can be either airborne, or propagated by direct or liquid contact with a waveguide. Use of medical ultrasound devices are governed by stringent standards and regulations (Duck, 2007).

For cutting and ablation of soft tissues, such as blood vessels, or hard tissue such as bone, cited advantages of an ultrasonic surgical instrument are safety (Amaral, 1994), precision (Khambay and Walmsley, 2000a; Kinoshita et al., 1999), and improved haemostasis (Kadesky et al., 1997).
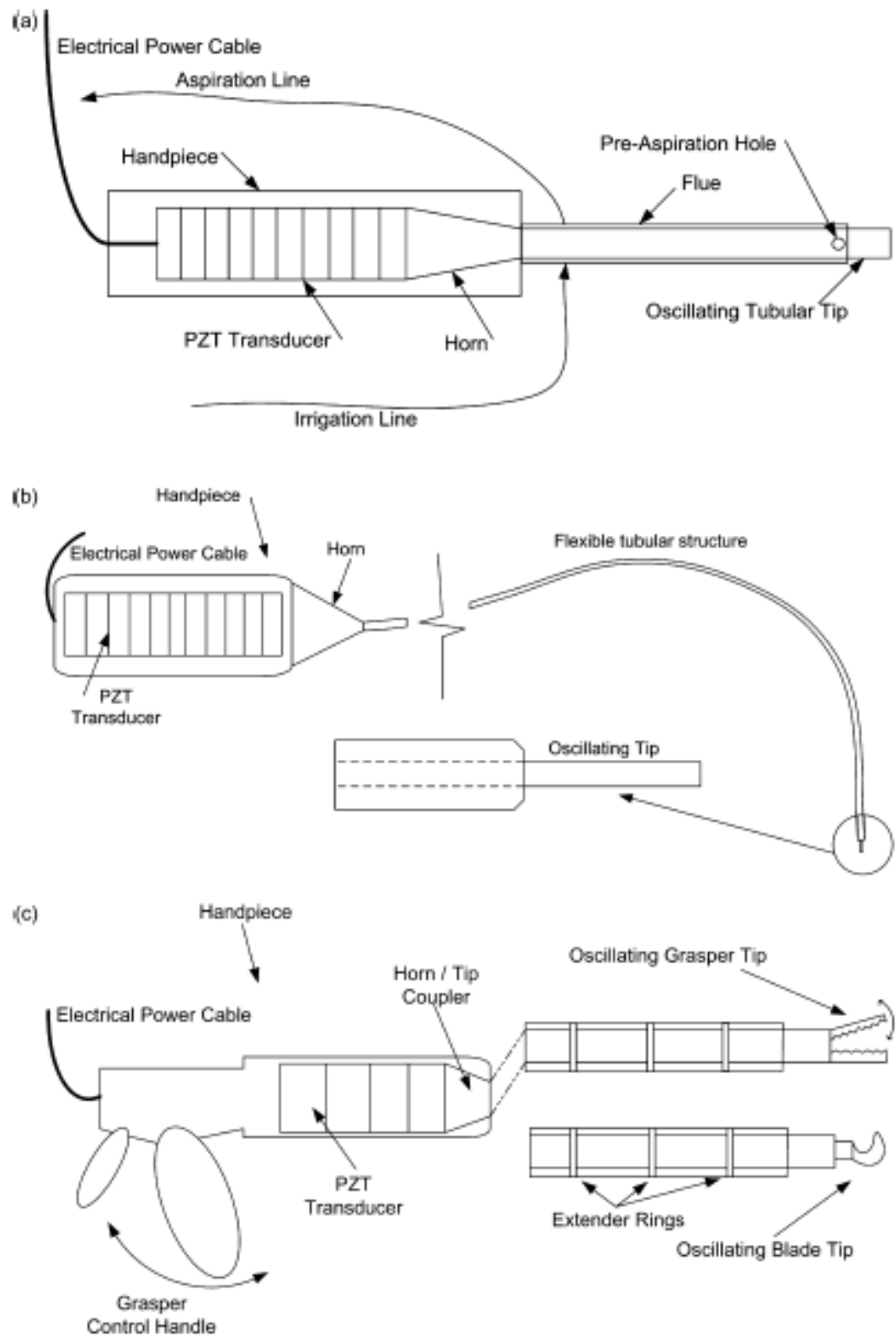

Fig. 1 - (a) Schematic configuration of generic ultrasonic device for soft tissue ablation, illustrating ultrasonic handpiece with plezoelectric transducer, converter, acoustic hom and oscillating tubular probe-tip with suction (aspiration) and irrigation components. (b) Schematic configuration of generic ultrasonic device for vascular tissue ablation with cannulated flexible wire waveguide. (c) Schematic configuration of generic ultrasonic device for tissue cutting illustrating possible end-effector tissue grasping and hook-blade tips. 
Ultrasonic dissection systems are known to expedite considerably the conduct of complex laparoscopic operations, especially colorectal resections (Emam and Cuschieri, 2003). Applications where this technology is licensed and in current clinical use are dentistry (Walmsley, 1988), phaco-emulsification in ophthalmology (Kelman, 1973), tissue dissection in abdominal surgery (Isomura et al., 1998), bone cutting in orthopaedic (Nakase et al., 2006) and maxillofacial surgery (Vercellotti, 2004), neurosurgery (Inoue et al., 2000), selective fragmentation and removal of pathological (e.g. tumour) tissue (Wuchnich et al., 1977), bone cement removal (Burstein et al., 2004) and lipoplasty (Zocchi, 1992). More recently, technology has been licensed for vascular plaque ablation in the treatment of chronic total occlusion (Weisz and Moses, 2007).

Clinical device application and operating characteristics are summarized in Table 1. Two principal forms of vibratory energy find application in medicine and surgery (Cimino, 1999). These are low-power high-frequency and high-power low-frequency ultrasound. Ultrasonic diagnostic imaging devices and ultrasonic physical therapy use low-power high-frequency vibratory energy $(1-20 \mathrm{MHz})$. If the ultrasound is focused, thermal damage can be created in tissues in a focal zone. This occurs in transcutaneous ablation of tumour tissues where an externally focused ultrasonic beam (frequency $\geq 1 \mathrm{MHz}$, power $0.5-3.0 \mathrm{~W} / \mathrm{cm} 2$ ) uses thermal effects to cause spotspecific tissue heating.

Alternatively, the vibratory energy may be unfocused, as in ultrasound diagnostic imaging (frequency $1-10 \mathrm{MHz}$, power $<0.05 \mathrm{~W} / \mathrm{cm} 2$ ). In contrast to both, ultrasonic surgery, the focus of this review, deploys relatively high-power $(10-300 \mathrm{~W} / \mathrm{cm} 2)$ lowfrequency $(20-60 \mathrm{kHz})$ vibratory energy.

This paper aims to review the current understanding of mechanisms of ultrasonic probe-tissue interaction and tissue effects of ultrasound for biological tissue application in the $20-60 \mathrm{kHz}$ ranges.

\subsection{History and evolution of ultrasonic instruments}

The evolution of ultrasonic cutting and ablation instruments is closely paralleled to the development of industrial ultrasonic machining for technological materials such as ceramics and metals. Principal advantages cited for industrial ultrasonic machining of metals and ceramics are reduced thermal damage and reduced residual stress levels compared with conventional laser and electrical discharge machining (Singh and Khamba, 2006). Ultrasound technology has been used for industrial materials processing for 80 years and in medical applications for over 50 years. The first patent for this technology was granted to American engineer Lewis Balamuth (1963a). Ultrasonic machining was initially described by Wood and Loomis in 1927 (Nishimura, 1954; Neppiras, 1956). In the same year, Wood and Loomis (1927) reported the first systematic investigation of biological effects of ultrasound. They used the piezoelectric effect developed by Langevin in 1917 for locating submarines 
by the echo of a narrow beam of high frequency sound waves (Langevin and Ishimoto, 1923).

Wood and Loomis's device consisted of a 2-kW oscillator, a bank of oil condensers, a large variable air condenser and several pairs of coaxial coils for raising the voltage. They used $7-14 \mathrm{~mm}$ circular quartz plates yielding waves with frequencies ranging from 100 to $700 \mathrm{kHz}$. They performed a variety of experiments showing the mechanical and thermal effects of high-intensity ultrasonic energy on small fish, mice and frogs. Subsequent examination revealed intra-abdominal bleeding. With vibrations of lower intensity, tissue destruction was reduced. This heralded the start of both safety and efficacy studies, and ultrasound therapy.

The Medical Device Amendments regulations were passed in 1976, controlling the sale and supply of ultrasound equipment for medical uses. In the US, manufacturers are required to provide information on acoustic output when applying to the United States Food and Drug Administration (US FDA) and submit a 510(k) pre-market notification (FDA, 1997). Similar legislative processes apply in Europe and elsewhere, broadly applying the same criteria.

These are guided by international standards including those published by the international electro-technical commission (IEC, 2005). 


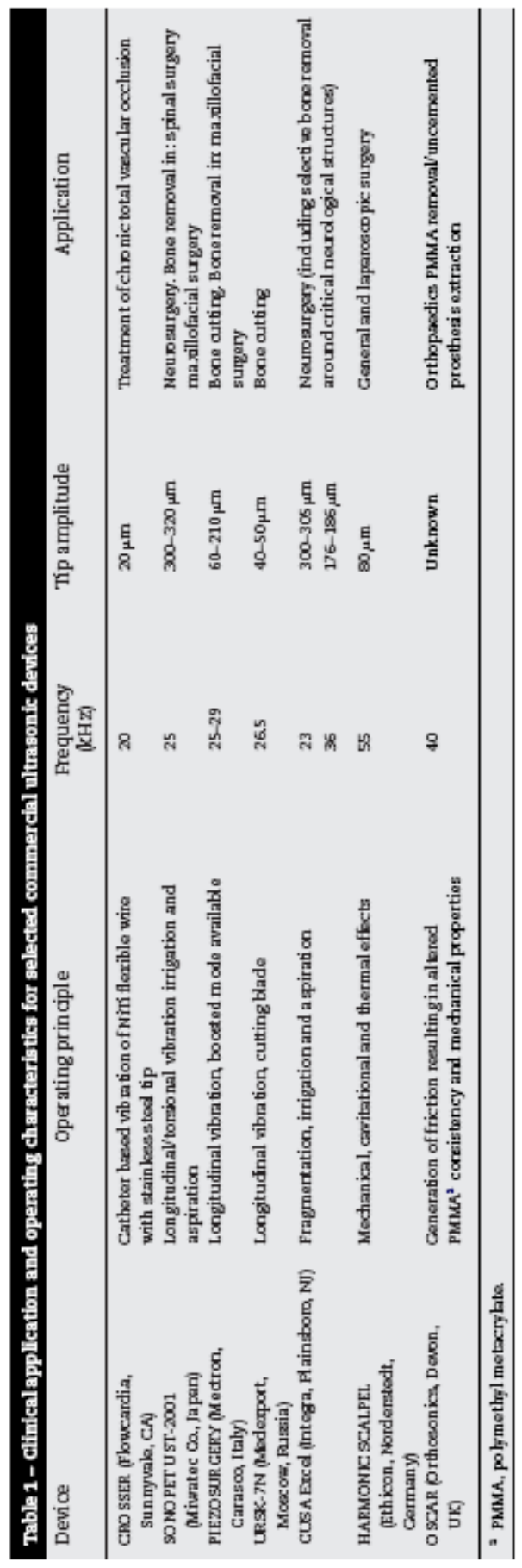

\subsubsection{Dentistry}

The first reported use of ultrasound in dentistry was by Balamuth in 1952 when an industrial ultrasonic grinder was used to prepare cavities in extracted human teeth (Balamuth, 1963b). In 1970, Balamuth patented use of ultrasonic frequency vibratory forces for removal of layers of highly compliant biological tissue (Balamuth, 1970). In this patent, he describes use of vibratory forces to create a 'microchipping' effect for tissue removal. It was realised that certain resonant frequencies could be used in dental scaling to remove calculus from teeth while selectively preserving the 
gingival, dentin and enamel (Walmsley et al., 1984). This is now a widely accepted dental procedure (Walmsley et al., 1992).

\subsubsection{Phaco-emulsification}

In 1967, Kelman reported the use of a combination of low frequency ultrasound and aspiration for removal of human tissue (Kelman, 1967). However, the focus of Kelman's study, the first describing lens phaco-emulsification in cataract surgery, and subsequent reports (Kelman, 1973), is end clinical result alone and does not explore the mechanism of device-tissue interaction. Collateral damage to the cornea is now known to result from this interaction and studies have been performed to control the extent of cavitation while reducing the undesirable collateral damage in the cornea (Anis and PhacoTmesis, 1999).

\subsubsection{Soft tissue cutting}

Flamm et al. (1978) used a more powerful version of the phaco-emulsification unit to study the effect of ultrasound on cat brain and spinal cord tissue, concluding that this was an effective method of tissue fragmentation in tissues with significant water content. Histological analysis demonstrated haemorrhage, necrosis and oedema in spinal cord tissue. No evaluation of the acoustic energy delivered or the mode of interaction was reported. Amaral (1994) has proven the efficacy of a hook-spatula blade for laparoscopic surgery application based on observation effects of cutting and coagulation efficacy in animal studies.

\subsubsection{Bone cutting}

In 1955, Vang described a high-frequency longitudinal vibrating surgical cutting instrument for bone in which the drive motor consisted of an inducer-inductor associated with oscillation frequencies in the 6-12 kHz range (Vang, 1955). In 1974, Volkov reported his 5-year experience of 311 cases, simplifying orthopaedic procedures using an ultrasonic cutting device (Volkov and Shepeleva, 1974).

His device used a 25-30 kHz mechanical longitudinal vibration to drive an endeffector (scalpel or saw), which was modified depending on the task performed. Peak-to-peak distal-tip vibration was greater than 50 $\mathrm{m}$. He concluded that simple orthopaedic operations could be performed through a smaller incision than before. Polyakov (1972) also reported successful use of this instrument in cutting, sawing and uniting bony fractures. Success has been reported for ultrasonic bone scalpels used when performing precise bone osteotomy (Hoigne et al., 2006; Vercellotti et al., 2001).

Frequencies of 25-29 kHz are specific for cutting mineralized tissue, reducing the risk of nerve and vessel damage. Advantages have been claimed in removal of callus 
from titanium osteosynthetic material, in particular callus from the slots of screws allowing fixation plate removal, without damage (Eggers et al., 2004).

\subsubsection{Lipoplasty}

Since the late 1980s, ultrasonic surgical systems have been used to fragment and remove fatty tissue in lipoplasty (Zocchi, 1992; Cimino, 1999). The earliest clinical data were reports bym Scheflan and Tazi reporting their experience in 800 patients (Scheflan and Tazi, 1996) and Kloehn in over 600 patients (Kloehn, 1997). Experience with this technique has been positive but concerns exist regarding the long-term deleterious effect of ultrasonic energy interaction with residual tissue (Cooter et al., 2001; Topaz, 1998). In 2001, the Australian Safety and Efficacy Register of New Interventional Procedures- Surgical (ASERNIP-S) reviewed the risks (Cooter et al., 2001) associated and concluded that: "The safety and/or efficacy of the procedure cannot be determined at the present time due to an incomplete and/or poor quality evidence-base."

To date, similar reviews for ultrasonic instruments for other applications have not been published by Safety and Efficacy Registers in Australia or elsewhere (Campbell and Maddern, 2003).

\subsubsection{Bone cement removal}

Successful use of ultrasound in dentistry led to adoption of ultrasonic cement extraction in orthopaedics (Burstein et al., 2004). This has the advantage of preserving patient bone stock and preventing bone perforation during revision total hip arthroplasty (Brooks et al., 1993, 1995; Gardiner et al., 1993;

Klapper et al., 1992). A major advantage of the ultrasonic system is the ability to detect the difference between cutting through bone cement and coming into contact with cortical bone (dense bone forming the surface of bones). The ultrasonic tool bit buzzes or 'sings' if any attempt is made to cut cortical bone (Callaghan et al., 1992). This tactile auditory feedback mechanism is an important = safeguard against femoral perforation.

\subsubsection{Cardiovascular}

In 1940, the effect of ultrasonic energy on biological tissue had become apparent to Conte and Delorenzi in studies on echocardiography and cardiac doppler measurements (Edler, 1989). The biological effects observed were classified as heating, stirring, microrupture and chemical change, for brain and spleen tissue (Conte and Delorenzi, 1940). In 1965, Anschuetz and Bernard examined the effects 
of ultrasonic energy for atherosclerotic plaque ablation (Anschuetz and Bernard, 1965).

Their study concluded that normal and atherosclerotic arteries are more resistant to damage from ultrasound than skin, fat, muscle, or liver. The development and testing in vivo of apparatuses for arterial catheterization and thrombolysis began in the early 1970s when Sobbe et al. (1974) delivered ultrasonic vibrations via a wire probe resulting in the disruption of vascular plaques in animal studies. From the mid1980s, much investigation has focused on design issues specific to delivery of ultrasonic energy through the tortuous vascular tree to the plaque location (Siegel et al., 1988; Rosenschein et al., 1991; Ariani et al., 1991; Demer et al., 1991).

This work enabled ultrasonic delivery through tortuous vascular structures via narrow diameter flexible nickel-titanium (NiTi) and other stainless steel transmission wires coupled directly to an acoustic horn for vascular plaque ablation. In 1994, Siegel et al. presented experimental ex vivo studies and initial clinical experience with a 19.5 $\mathrm{kHz}$ ultrasonic waveguide for occluded coronary arteries (Siegel et al., 1994). Increased distensibility of the ex vivo calcified arteries following exposure to the ultrasonic energy was observed (Siegel et al., 1994).

They postulated that this could have the effect of reducing the balloon pressures required for stenting procedures, thereby increasing safety, after a lesion has been crossed with a guide wire. Demer et al. (1991) and Rosenschein et al. (1990) have similarly reported favourable results for in vivo and ex vivo experiments on calcified atherosclerotic material.

Since 2005, ultrasonic ablation for chronic total occlusion has been licensed for clinical use in the European Union (EU). Clinical trials have been promising with minimal complication rates reported (Weisz and Moses, 2007; Grube et al., 2006; Melzi et al., 2006; Ali et al., 2006). The granting of US FDA approval for this device is based on the manufacturer's claims of substantial equivalence in intended use to a radiofrequency ablation catheter, not withstanding their different energy source and without published experimental evidence to support comparable tissue interaction and damage mechanics (FDA, 2007).

\subsection{Current status}

Although the clinical use of therapeutic ultrasound is well documented, our understanding of ultrasound-tissue interaction, removal and damage is predominantly subjective and based on clinical observation alone. Moreover, the interaction between ultrasound and living tissue is complex and poorly understood (Chan et al., 1986; Bond and Cimino, 1996; Beissner, 1980; Cimino and Bond, 1996; Cimino, 1999). For tissue applications, ultrasonic instrument design has historically been conducted on a semi-empirical basis, by successive improvement in design during many time-consuming iterative steps (Wiksell et al., 2000). In contrast to the 
published work for ultrasonic processing of metals and ceramics, there is a paucity of the literature and models for the investigation of ultrasonic tissue processing. Little mechanical or morphological characterisation has been presented to illuminate any adverse structural tissue damage effects of ultrasonic energy.

Neither have sufficiently comprehensive mechanistic or mathematical models for the behaviour of individual tissues been proposed. Few studies examining the cutting or ablation ability of ultrasonic instruments for fragmentation of soft tissue and hard tissue have been conducted (Wiksell et al., 2000). The interaction is known to depend on type of tissue, its condition, mode of ultrasound application and several acoustic parameters, including frequency, tip area, tip shape, amplitude and resulting pressure or intensities (Cimino and Bond, 1996). Factors known to influence cutting ability of ultrasonic chisels include cutting rate, force and depth of cut (Khambay andWalmsley, 2000b). An improved understanding of effects of altering these input parameters should ultimately contribute to increased instrument efficacy and shorter leadtime in the development of new instruments. 


\section{Physics of ultrasonic medical and surgical devices}

\subsection{Ultrasound generation}

An ultrasonic surgical hand piece is primarily an acoustic assembly that includes four basic elements. These are a generator or power supply, an ultrasonic motor (transducer), a mechanical wave amplifier (referred to as an acoustic horn) and a sonotrode (or probe) (Fig. 1a-c).

The generator converts low-frequency into high-frequency electrical power. This electrical signal is supplied to the transducer for conversion into longitudinal or transverse low amplitude mechanical vibrations (Thoe et al., 1998). Electric energy supplied by the ultrasonic generator is converted to high-frequency vibratory energy (20-60 kHz for the applications reviewed) by the transducer, a piezoelectric stack. When a voltage is applied to a piezoelectric material, the structure changes shape, acting as an electromechanical transducer.

These geometric changes are usually of the order of a few microns, and the voltage amplitudes required to produce them are large. Vibrations are then transmitted to a horn, which is used to increase or decrease the amplitude of the vibrations. These vibrations are finally transmitted longitudinally along the length of the probe. The horn and tip are normally profiled to achieve a specified mechanical gain. Acoustic horns are solid metal rods that are designed to couple to the front-end mass of the converter and resonate at the same frequency as the transducer.

They achieve an increase in output displacement by two means. Firstly, their geometry is such that the input wave is compressed through a progressively smaller cross-sectional area as it travels the length of the rod resulting in a larger displacement at the output. This is clearly seen in both linear and exponentially tapered horns (Perkins, 1986). Secondly, horns can be manufactured to resonate at the frequency of the ultrasonic converter. For most clinical applications, a combination of both stepped and tapered sections are used in horn design. Horns are manufactured from materials that have high dynamic fatigue strength and low acoustic loss, such as titanium alloys. Longitudinal acoustic waves are delivered to the probe-tip and manifest as a periodic distal-tip axial peak-topeak displacement.

\subsection{Delivery of ultrasound to tissues}

Tissue removal and damage occurs when the vibrating metal probe is brought into contact with tissue such that it is cut, dissected, fragmented, ablated or coagulated. As the energy is concentrated at the tip, acoustic power densities at the probetissue interface of ultrasonic surgical devices are much higher than that of diagnostic and physical therapy ultrasound devices, with values ranging from 25 to $850 \mathrm{~W} / \mathrm{cm} 2$ (Cimino, 1999) Unlike the latter, the energy target is not at a distance from the applicator. Rather, effects are seen in the tissues that have direct contact 
with the ultrasonic probe and in adjacent tissue over a range believed to be in the order of $0.01-0.1 \mathrm{~cm}$, depending on application. The treatment goal is destruction or alteration of tissues in close proximity to the probe-tissue interface rather than propagation of vibratory energy in the tissues. The range or area over which clinically relevant ablation or fragmentation effects occur in these systems has not been elucidated. A review of hypothesised mechanisms of interaction is presented in Section 3.4.

\subsection{Component design consideration}

For efficient material removal, instruments must be designed with consideration given tomass and shape so that resonance can be achieved within the frequency range capability of the ultrasonic machining instrument (Singh and Khamba, 2006). Ultrasonic surgery systems present the operator with multiple settings, alterations in which can directly affect clinical outcome.

These include amplitude setting, probe or tip design, probe diameter, vibration frequency and mode of energy delivery. No standard objective means of representing distal output conditions in a user interface for these systems has been accepted. Collection of universally applicable data has not been described for such systems. This datawould provide clinicians with a standard of comparison for all available devices for a given application.

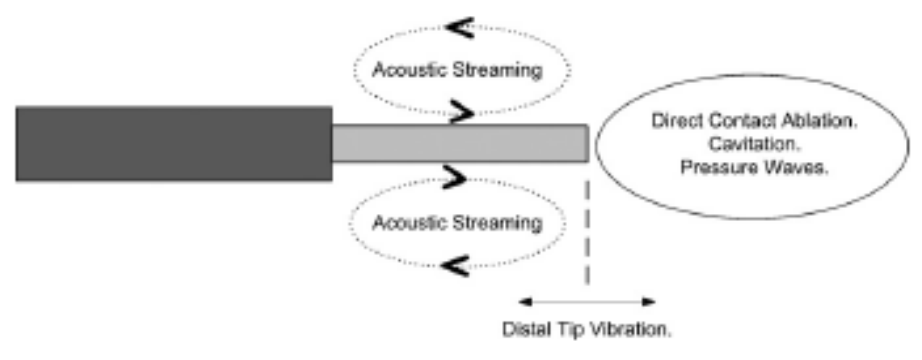

Fig. 2 - schematic of mechanisms of fluid and tissue interaction.

\subsubsection{Amplitude}

Ultrasonic instruments vibrate with total excursion of only a few hundredths of a millimetre in a direction usually parallel, or alternatively transverse to the axis of the waveguide.

Maximum amplitudes of tip vibration range up to several hundred microns. Cimino and Bond studied experimentally the physics of ultrasonic tissue fragmentation, using an ultrasonic device operating at $12-36 \mathrm{kHz}$, with a hollow cylindrical Ti probe vibrating at a maximum amplitude of $300 \square \mathrm{mp}-\mathrm{p}$ (peak-to- peak) at its distal-tip for soft tissue fragmentation and aspiration. This device incorporates suction (0$600 \mathrm{mmHg}$ ) and irrigation (1-3 ml/min) (Cimino and Bond, 1996). In this work, they show that tissue fragmentation rate is a direct function of stroke amplitude. 


\subsubsection{Probe/end-effector configuration}

There is considerable variation in probe length, diameter and end-effector (tip) design depending on application. Overall, the acoustic assembly has a resonant frequency that is determined by the assembled length of its constituent components. Efficient and useful vibration occurs only when the acoustic assembly is vibrated at its intended frequency. Gavin et al. (2007) have shown numerically and experimentally the critical effect of wire length on the output $\mathrm{p}-\mathrm{p}$ displacements achieved as the waveguide length is changed between resonant and anti-resonant lengths for a NiTi wire. Their numerical model has the potential to be developed for instrument design for other tissue applications.

In medical applications, the area of the applicator is small, typically between 0.01 and $0.2 \mathrm{~cm} 2$. Cimino and Bond have shown experimentally that when tip area is reduced, a corresponding reduction in fragmentation rate is observed (Cimino and Bond, 1996).

The material used in probemanufacture affects instrument performance. Considerationmust be given to device shaft configuration to minimize power loss and heat generation. The metal probe may be solid or tubular, or any configuration. Amaral (1994) describes the use of titanium formanufacture of ultrasonic blades for laparoscopic use. Titanium blades resist cracking and shear forces. In previous studies, aluminium was used for blade construction. This results in stress fracture of blades, impairing acoustic signal and increasing impedance.

Additionally, aluminium blades crack when they are exposed to hard substances such as bone or metal, or subjected to heavy pressure. Rawson, in 1993, patented a device incorporating vibration ofmultiple ultrasonic blades transverse to the plane of passage of the blade through a material when the cutting device is in operation (Rawson and Morris, 1993). This increased the depth of cut obtainable with an ultrasonic cutting device and increased the range of materials that can be cut using an ultrasonic device.

The shape of the end-effector or probe-tip has a direct and significant effect on tiptissue interaction. Ultrasonic energy coupled to the tissues can be concentrated by the tip design to generate cutting effects, dispersed by the tip design to generate broad fragmenting or coagulating effects or specifically shaped to minimize cavitational effects (Cimino, 1999). This knowledge has been exploited in design of instruments for clinical applications. Examples include thin-edged cutting hooks, clamp jaws or ball-ends in ultrasonic laparoscopic surgery instruments, blunt cut tubes with central aspiration lumens in neurosurgery, chisel ends for bone cutting and blunt cut or chisel-end instruments with central lumens for phaco-emulsification. However, impact of such alterations in probe-tip design is difficult to analyse quantitatively. In general, qualitative classification of cutting blade sharpness for biological materials is based on rated observation of characteristics of the cutting 
surfaces and cutting edges (Reilly et al., 2004). Systems in use rate sharpness by numerical scales.

No means has been proposed to assess comparative performance on a scaled basis of a cutting edge for a range of different cutting instruments (Reilly et al., 2004). Blade complexity and diversification of variables associated with edge profile make it extremely difficult to derive a functional system that is capable of giving comparative results. Reilly et al. (2004) concluded that evaluation of the status of the material after non-ultrasonic cutting offers the greatest potential in assessment of sharpness. Measurements of edge and sharpness characteristics have been described for other surgical cutting instruments, but not to date for ultrasonic instruments. Lucas et al. have used vibration analysis by experimental and finite element analysis (FEA) to characterise vibration behaviour of single and multiple ultrasonic cutting blades. This has improved understanding of vibration responses occurring in response to design modifications and permitted enhanced cutting tool efficiency (Lucas et al., 1996, 2001; Cardoni et al., 2004).

\subsubsection{Suction}

For instruments whose function is to remove biological tissue by ablation or fragmentation, a hollow tool is used which provides suction at the interaction site for debris aspiration or removal. In comparison, instruments intended for material cutting such as ultrasonic dental drills, ultrasonic scalpels and bone cutters do not employ integral suction. For commercially available devices, suction pressure is continuous and in the range $550-600 \mathrm{mmHg}$ (Chan et al., 1986). The purpose of the suction is claimed to be twofold. Firstly, it functions to aspirate fragmented debris via the hollow lumen and secondly, to counteract the positive acoustic pressure close to the tip of the ultrasonic device (Cimino and Bond, 1996). In the absence of the negative pressure, tissue moves away from the vibrating probe and no ablation occurs. When present, the suction pressure draws the tissue into or against the probe end-effector for effective ablation. Suction units that are uncontrollable in terms of amount of suction they exert can significantly injure vascular and neural tissues (Sundt et al., 1991). Provision of a simple in-built universal regulatory suction control permitting safer intermittent suction has been proposed by Egemen (1992).

\subsubsection{Power}

Electric power supplied to the ultrasonic instrument by the ultrasonic generator and the acoustic or vibratory power. Typical power ratings encountered are in the range $5-25 \mathrm{~W}$, depending strongly on the design of the system. The latter is the power that is coupled to and flows into the probe-tissue interface or the tissue, resulting in a 
surgical cutting or ablation effect. Typical values seen during various types of ultrasonic surgery range between 1 and 10W, with maximumvalues of 20W(Cimino, 1999). For comparative purposes, electrosurgical systems used to cut and coagulate tissue at commonly used clinical settings deliver from 30 to $100 \mathrm{~W}$ to the tissues, depending on power setting (Cimino, 2001). A differential electric measurement method using the difference between powers consumed by an ultrasonic device operating in air and under a tissue load has been described (Cimino and Bond, 1996; Cimino, 1999). This method can be readily used to quantify the amount of acoustic power flowing into the tissue (Levy and McComb, 1999).

\subsubsection{Loading characteristics}

Loading is known to affect the operative characteristics of an ultrasonic probe. This was first observed clinically by Aro et al. (1981) who noted that an ultrasonic scalpel needed to be regulated at the generator to maintain optimal vibratory frequency. Theoretical and experimental study has been conducted by Lin (2005) on the effect of load on the resonance frequency of sandwich piezoelectric transducers using an equivalent circuit model. They demonstrated that electric load impedance (including load resistance and inductance) has different effects on resonant frequency, anti-resonant frequency and electromechanical coupling coefficients of ultrasonic transducers. As the load resistance is increased, the effect on the effective electromechanical coupling coefficient becomes negligible (Lin, 2004). In contrast to industrial ultrasonic machining applications, mathematical models have not been proposed for human tissues functioning as a load on an ultrasonic probe. One difficulty is that biological tissues are not homogeneous structures and individual tissues present unique and different loads to the ultrasonic probe.

This results in alteration of probe working characteristics, even during a given application. With soft tissue loads such as fat, muscle, liver, skin and cartilage, resonant frequency of an ultrasonic probe shifts to a lower working frequency compared to unloaded operation in air. Conversely, resonant frequency shifts to a higher frequency when the probe is loaded in cancellous or cortical bone. This has been demonstrated by Ying et al. (2006) using an ex vivo porcine animal model. They used an equivalent circuit model to represent the system comprising an ultrasonic scalpel (ExploiterTM, Beyonder Co. Ltd., Beijing, China) operating at $40 \mathrm{kHz}$ and soft and hard tissues. Clinically, such variation is most pronounced when cutting or ablating hard tissues such as bone, as it is invariably surrounded by soft tissues and usually variations in densities and strengths exist within the bone between spongy and compact bone. However, a mechanistic model of loading conditions is not provided in this paper. They propose further study of a mathematical model with ability to separate ultrasonic instrument and tissue loads, and analyse their interaction (Ying et al., 2006). 


\begin{tabular}{|c|c|c|c|c|c|}
\hline Study & Device/operating parameters & Application & Tissue/host properties & Findings & $\begin{array}{l}\text { Residual tissue } \\
\text { ondition/experimental } \\
\text { observations on MOA }\end{array}$ \\
\hline Aro et al (1981) & 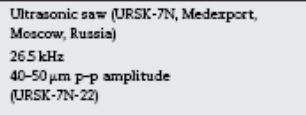 & $\begin{array}{l}\text { Bone cutting (ulns; } \\
\text { scapuls; tibias) }\end{array}$ & Ratbit, in vivo & - & $\begin{array}{l}\text { Histoloळ: thermal necrosis } \\
\text { SEM: rough surface }\end{array}$ \\
\hline Amaral (1994) & $\begin{array}{l}\text { Utrasonically activated gcalpel (Harmonic } \\
\text { Scalpel, UltraCision Inc, Smithfeld, RI) } \\
55 \mathrm{kHz} \\
80 \mathrm{~mm} \text { F-p amplitude }\end{array}$ & $\begin{array}{l}\text { Laparoscopic } \\
\text { cholecystectorny }\end{array}$ & Pig, in vivo & 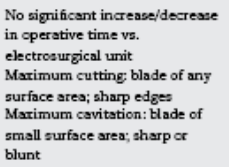 & $\begin{array}{l}\text { Gross: Liver: tissue blanching, no } \\
\text { charring } \\
\text { Gall tladder: no visual evidence thermal } \\
\text { injury }\end{array}$ \\
\hline Kodesky et al. (1997) & $\begin{array}{l}\text { Utrasonically activated gcal pel (Harmonic } \\
\text { Scalpel, UltuaCision Inc, Smithbeld, RI) } \\
\text { Not stated }\end{array}$ & $\begin{array}{l}\text { Laparotomy//aparcecopy } \\
\text { and tiesue dizsection }\end{array}$ & Pig (iver, ureter), in vive & $\begin{array}{l}\text { Easier dibsostion and improved } \\
\text { hasmostasis rac, conventicnal } \\
\text { instruments }\end{array}$ & $\begin{array}{l}\text { Histology: loss of cellular architecture } \\
\text { and trane-mural thermal necrosis }\end{array}$ \\
\hline Kinceshits et al. (1999) & $\begin{array}{l}\text { Ultrasonically actirsated gcalpel (ScnoSurg, } \\
\text { Olympuz Optical, Tokga, lopan) } \\
235 \mathrm{kHz} \\
200 \mathrm{\mu m} \text { p-p amplitude }\end{array}$ & Laparotomy & Pig, in vivo & $\begin{array}{l}\text { Zone of thermal damage } \\
\text { reduced vz electrosurgery } \\
\text { device }\end{array}$ & $\begin{array}{l}\text { Histoloø: thermal necrosis } \\
\text { Smoother cut margin wo. elctrosurgery } \\
\text { device }\end{array}$ \\
\hline $\begin{array}{l}\text { Khambay and Walmsley } \\
\text { (2000a) Part } 1\end{array}$ & $\begin{array}{l}\text { Research ultrasonic chisel } \\
30 \mu \mathrm{m} \text { P-p amplitude } \\
\text { Straight tip } \\
\text { Irrigation }\end{array}$ & Bone cutting & Bovine bone, ex vivo & Rate of cut: $26-110 \mathrm{~mm} / \mathrm{min}$ & - \\
\hline $\begin{array}{l}\text { Khambay and Walmeley } \\
\text { (2000) Part } 2\end{array}$ & & & & $\begin{array}{l}\text { Analygis of variations in rate of } \\
\text { cult vith alteration of rake engle } \\
\text { Analysis of variations in depth } \\
\text { of cut with alteration of rate of } \\
\text { cut }\end{array}$ & \\
\hline Surs et al. (2001) & $\begin{array}{l}\text { Ultrasound generator and TFl-1 tip } \\
\text { (Denteply, UK) } \\
25 . \mathrm{HA} z \\
9.84-18.2 \mu \mathrm{mp} \text {-p armplitude } \\
\text { Chisel-tip }\end{array}$ & Bone cutting & $\begin{array}{l}\text { Rat, primary osteoblast } \\
\text { cultures (Albino Wistar } \\
\text { ratso), in vïro }\end{array}$ & $\begin{array}{l}\text { Incressed ostasblast } \\
\text { detathrment =ith incressed tip } \\
\text { displssement }\end{array}$ & $\begin{array}{l}\text { Redused osteotlast vistility with } \\
\text { increased tip dieplasement }\end{array}$ \\
\hline Emam and Cuschieri (2003) & $\begin{array}{l}\text { (1) Ultrasonically activated øcalpel } \\
\text { (Ultracision, Ethicon-LCS-B5, Norderstedt, } \\
\text { Germany) and }\end{array}$ & $\begin{array}{l}\text { Laparotomy//ap aroscopy } \\
\text { and tizave dizuestion }\end{array}$ & Pigg, in vivo & - & $\begin{array}{l}\text { IR camera measurement of residual } \\
\text { tissue tempera ture elevation } \\
\text { Histology: thermal damage }\end{array}$ \\
\hline & 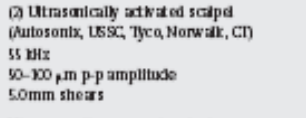 & & & & $\begin{array}{l}\text { Me an peak tempenature ganeration In } \\
\text { ussue propautona to artiation tme } \\
\text { and power attlng }\end{array}$ \\
\hline Kodh et al. (200) & 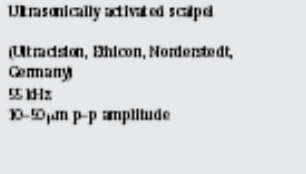 & Son ussue dissection & $\begin{array}{l}\text { Fg } \alpha \text { vioand invtoouung. } \\
\text { tangue, parotud gind) }\end{array}$ & - & 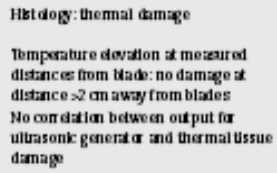 \\
\hline
\end{tabular}

\section{Tissue removal and damage mechanisms}

\subsection{Background}

The mechanism of material removal is well documented for industrial ultrasonic machining applications. These mechanisms include mechanical abrasion by direct hammering of abrasive particles against the tool surface, microchipping by impact of free-moving abrasive particles and cavitation effects from the abrasive slurry (Thoe et al., 1998). Their combined effect results in shear, fracture and material removal from the surface. For porous materials, such as graphite, cavitation erosion is a significant contributor to material removal. Available evidence supports similar mechanisms in biological tissues (Cimino, 1999; Atar et al., 1999). All these mechanisms are directly related to the distal-tip displacement, amplitude and frequency (Fig. 2). 
The mechanics of biological soft tissues has received considerable attention (Humphrey, 2003). However, precisely how and why the mechanism of tissue removal and damage differs for individual tissues depending on whether they are soft (e.g. lipid, visceral tissue), elastic (blood vessels) or hard (calcified vascular plaque, intraocular lens, bone) remains unclear. The response of biological tissue to ultrasound can be quite variable and depends on the acoustic and biological properties as well as on location and function of exposed tissue (Barnett et al., 1997). Soft tissues are composed of a long-chain, cross-linked polymeric structure, similar to that of elastomers. Most soft tissues exhibit a nonlinear, inelastic, heterogeneous anisotropic character that varies from point to point, from time to time and from person to person (Humphrey, 2003). Absorption of ultrasound propagation in tissue has been studied by Goldman and Hueter (1956).

They complied an expansive table of data on absorption of ultrasound in various tissues. They found that bone has an absorption coefficient many times greater than soft tissue. It has been established that absorption coefficient increases as a function of protein content, with collagen having particularly high specific absorption (Goss et al., 1979; NCRP, 1983).

Collagen accounts for up to $80 \%$ of the protein in tendon, but less than $20 \%$ in brain, kidney and liver. Collagen is primarily responsible for tissue tensile strength. For imaging applications, albeit typically at higher frequencies, the absorption coefficient values for brain, liver and kidney range from 0.2 to $0.6 \mathrm{~dB} / \mathrm{cm} \mathrm{MHz}$. Higher absorption values, with the consequent potential for undesirable ultrasound-induced heating, are found in more elastin- and collagen-rich tissues such as skin and tendon (1 dB/cm MHz). In harder tissues, (e.g. bone) an absorption value of $10 \mathrm{~dB} / \mathrm{cmMHz}$ is reported (Barnett et al., 1997).

\subsection{Cavitation}

Cavitation is now recognized as an important factor contributing to the success of numerous biomedical applications or as an inherent feature of ultrasonic processes. An oscillating acoustic pressure field, superimposed on the ambient pressure, is established around the distal-tip (Nyborg, 1996; Makin and Everbach, 1996). Cavitation occurs when, on the negative side of a pressure cycle, such as when the probe-tip is retracting with sufficient amplitude and frequency, suspended gas bubbles either within fluid, tissue or trapped at solid interfaces expand and collapse resulting in the generation of shock waves.

Ultrasonic cavitation bubbles have complex dynamic behaviour. Fong et al. have experimentally studied the interaction of a cavitation bubble and adjacent biomaterial in an ultrasound field. They observed that cavitation bubble behaviour is highly sensitive to different types of biomaterial (Fong et al., 2006). They describe the interaction of cavitation bubbles with a range of biomaterials. When these bubbles collapse, jet-like ejection into the fluid occurs, with very high maximum velocity jets 
directed away from, or towards the biomaterial (700-900ms-1) (Brujan et al., $2001 a, b)$. The bubble oscillates and either forms a jet or splits into two smaller bubbles. Cavitation may have significant mechanical effects because of the violent nature of the rapid collapse of cavitation bubbles. Variable responses were observed for the biomaterial in contact with the jet ranging from minimal motion (cartilage, bone) to attraction of material towards the bubble (fat, cornea). Theoretical models have been proposed for pressures generated in cavitation jets when the bubble collapses close to biomaterials, resulting in fragmentation of brittle objects such as dental tartar or intraocular lenses (Brujan, 2004). This process aids destruction at the probe-tissue interface. Others suggest that cavitation bubbles at the probe tissue interface may lead to inefficient coupling of vibratory energy to tissue and reduce tissue processing efficiency (Cimino, 1999). In clinical applications, it is unclear whether cavitation phenomena occur in intra-cellular, extra-cellular or surrounding fluid.

This theory suggests that within tissue, cavitation causes cell fragmentation and destruction and, in contrast, cavitation occurring in the surrounding fluid causes inefficient coupling with energy dissipated and no cellular fragmentation.

In the latter scenario, cavitation bubbles may be reflected back towards the probe in a linear jet and away from the tissue. This theory is supported by 'pitting' visualised in clinical practice at ultrasonic end-effectors (Cimino, 1999).

An increased understanding of bubble dynamics in an ultrasound field near a biomaterial may stimulate future improvements in instrument design and execution of ultrasonic biomedical processes.

\subsection{Direct mechanical impact}

Mechanical or direct 'jack hammer effects' occur when the vibrating probe acts as an ultrasonic reciprocating micro-drill.

Research in ultrasonic micromachining has shown that it is associated with low material removal rates by microchipping for ablation of brittle ceramic materials (Thoe et al., 1998).

Direct impact contact between the fast-moving oscillating tip and tissue results in fragmentation and ablation of material into microscopic particles. Repeated impacts may occur if the tissue is not fragmented in a single cycle. In various soft tissues, the mechanism is thought to be shear forces resulting from difference in force levels across a thin layer or boundary (Cimino, 1999). Additionally, two general forms of fluid motion are set up around an oscillating sphere in a fluid. The first can be considered a direct acoustic pressure wave or an oscillatory fluid motion very close to the wall of the tip and, the second, a unidirectional fluid motion in an external acoustic streaming layer. Their contribution to tissue removal is unknown. 
Fragmented tissue particles may create an abrasive slurry at the probe-tissue interface. This abrasive slurry is thought to propagate further material removal by material microchipping for industrial ultrasonic applications (Thoe et al., 1998; Moreland, 1984). It is possible that a similar mechanism occurs for harder biological tissue, although this has not been investigated.

Uniquely, mechanical effects of ultrasonic energy are tissue selective. This selectivity results from tissue strength, determined primarily by amount, type and organization of collagen in each tissue (Cimino and Bond, 1996). Stronger tissues with higher collagen content better withstand the vibratory insult from ultrasonic energy and do not fragment, where as weaker tissues will. In comparison to harder tissues, soft tissues are highly compliant and large amplitude and high-frequency vibrations can be used to fragment soft tissue with relative ease (Chan et al., 1986; Amso, 1994). This property is cardinal to the successful design of ultrasonic medical and surgical instruments. 


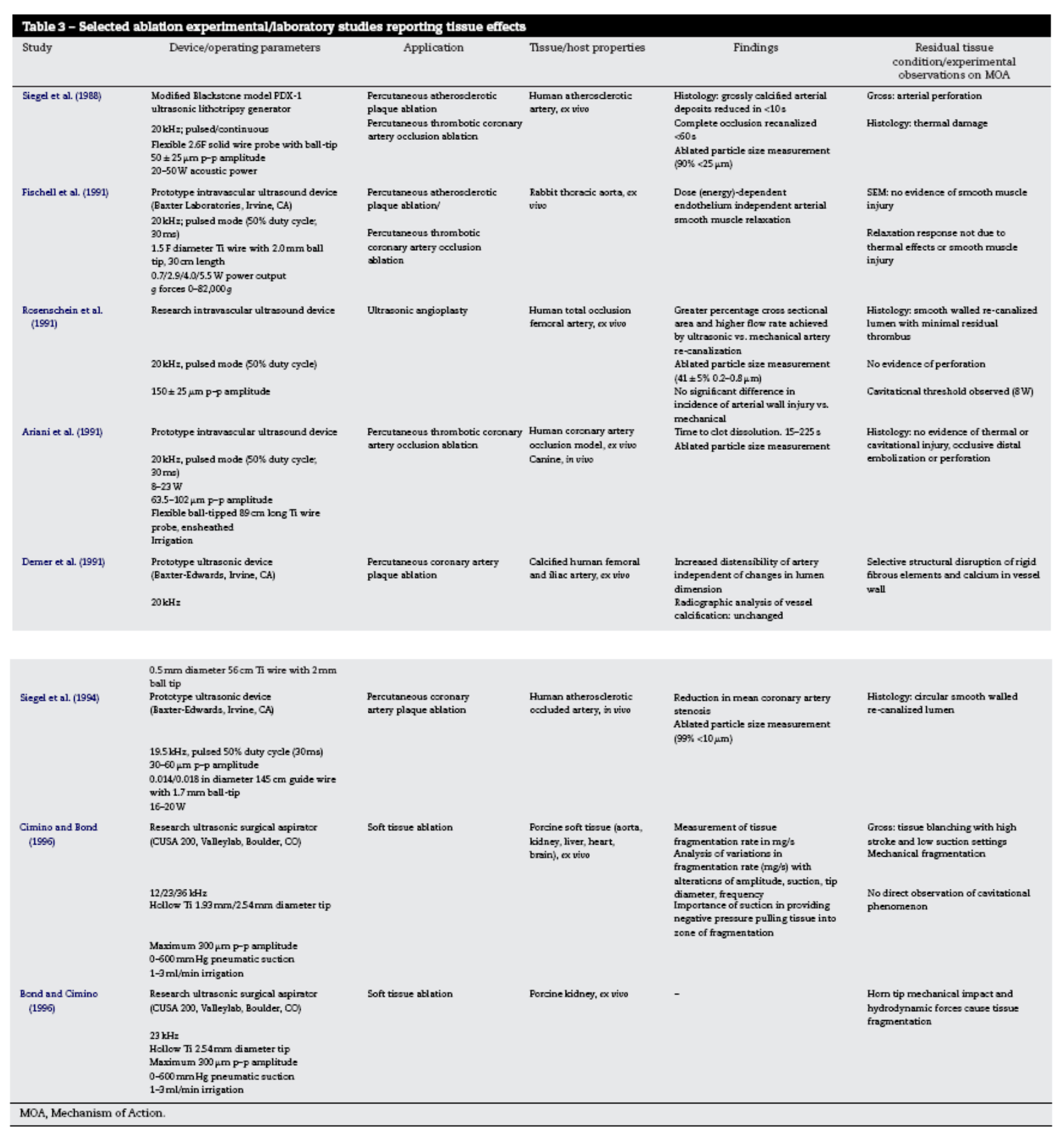

\subsection{Tissue interaction}

The literature reporting investigations of high-intensity ultrasonic surgical ablation and tissue failure mode in the frequency range of $20-60 \mathrm{kHz}$ is limited (Chan et al., 1986; Bond and Cimino, 1996; Cimino and Bond, 1996; Cimino, 1999). Several theories of interaction have been presented. Theories of interaction must account for the transformation, transmission, or loss of the ultrasonic energy into tissue.

Primarily, studies focus on macroscopic soft and vascular tissue removal. Few investigators have studied ultrasound probe-tissue interaction in detail. Studying the probe-tissue interface is problematic. Firstly, the tissue is continually destroyed through probe contact. Secondly, the time constants associated with its destruction are very short. Thirdly, biological tissues are not structurally homogenous. It had long 
been held that the primary removal mechanism was acoustic cavitation occurring either in intra- or extra-cellular fluid of cells. However, there is lack of robust evidence to support this from interaction mechanisms reported. The available literature supporting tissue removal and failure mechanisms for soft and hard tissues is reviewed and critically appraised in the following sections. Selected experimental and laboratory studies reporting mechanism of tissue interaction and residual tissue damage are presented for cutting (Table 2 ), ablation

(Table 3) and bone cement removal (Table 4).

\subsubsection{Phaco-emulsification}

For phaco-emulsification, mechanistic evidence comes solely from direct visualisation made by ophthalmic surgeons working with an ultrasonic phacoemulsification horn under a microscope. Here, the mechanism is now attributed to a combination of mechanical impact, shock waves in a fluid, surface impact of particles and cavitation (Seibel, 1993). Different ultrasonic frequency handpieces are thought to facilitate different mechanisms of action. A lower frequency (i.e. 29 $\mathrm{kHz}$ ) is thought to better facilitate cavitation. A higher frequency (i.e. $40 \mathrm{kHz}$ ) is thought to cut more smoothly with a mechanical 'jack-hammer' effect (Seibel, 1993).

\subsubsection{Soft tissues}

Bond and Cimino report that the mechanism in soft tissues is predominantly related to mechanical impact of direct shear, acoustic streaming and pressure wave components (Chan et al., 1986; Bond and Cimino, 1996; Cimino and Bond, 1996; Cimino, 1999). Although they report similar fragmentation rates for high amplitude low suction settings and for low suction high amplitude settings, observed tissue effects are markedly different. Optimal smooth clean fragmentation with little residual tissue damage and operator resistance is achieved for a range of settings between these two extremes. They conclude that the primary damage mechanism is horn tip impact and other mechanical and hydrodynamic forces applied to the tissue in the forward stroke of the cycle in concert with cavitation (Bond and Cimino, 1996). However, they do not present any histological information or mechanical characterisation to illuminate any gross or microscopic structural tissue damage effects in residual tissue. Lucus et al. studied ultrasound cutting of three separate materials with different mechanical properties (cheese, polyurethane foam and epoxy resin) (Lucas et al., 2006). They used a longitudinally vibrating horn operating at $20 \mathrm{kHz}$. They developed a two-dimensional FEA model for a multi-layered material, analogous to biological tissue encountered in surgical ultrasonic cutting. They found that friction at the blade-specimen interface decreased markedly when the ultrasonic device was operated. Their model incorporates an estimate of the 
friction condition between the cutting blade and tissue. Currently, optimal cutting conditions for materials are usually determined from experimental testing. Using this model, optimal settings for ultrasonic cutting devices can be predicted on a rational basis through adjustment of frequency, amplitude and cutting speed (Lucas et al., 2006).

\begin{tabular}{|c|c|c|c|c|c|}
\hline Study & Device/operating parameters & Application & Tissue/host properties & Efficacy & $\begin{array}{c}\text { Residual tissue } \\
\text { condition/experimental } \\
\text { observations on MOA }\end{array}$ \\
\hline $\begin{array}{c}\text { Caillouette et al } \\
\text { (1991b) Part 1 } \\
\text { Caillouette et al } \\
\text { (1991a) Fart 2 }\end{array}$ & $\begin{array}{l}\text { Prototype ultrasonic cement removal } \\
\text { device }\end{array}$ & $\begin{array}{l}\text { PMMA cement } \\
\text { removal }\end{array}$ & $\begin{array}{l}\text { Human femur with } \\
\text { prosthesis, ex vivo } \\
\text { Canine femur, in vivo }\end{array}$ & - & $\begin{array}{l}\text { No adverse temperature elevation } \\
\text { during ultrasonic prosthesis pull-out } \\
\text { Histology: no significant damage to } \\
\text { adjacent endosteal bone }\end{array}$ \\
\hline $\begin{array}{l}\text { Callaghan et al. } \\
(1992)\end{array}$ & $\begin{array}{l}\text { Prototype ultrasonic cement removal } \\
\text { device (Advanced Ossecus } \\
\text { Technologies, Aliso Veja, CA) }\end{array}$ & $\begin{array}{l}\text { PMMA cement } \\
\text { removal }\end{array}$ & $\begin{array}{l}\text { Canine femur with } \\
\text { prosthesis, ex vivo }\end{array}$ & $\begin{array}{l}\text { Reduced time during ultrasonic } \\
\text { prosthesis pull-out vs. manual }\end{array}$ & $\begin{array}{l}\text { No significant difference between } \\
\text { torsional bone strength after ultrasonic } \\
\text { vs. manual pull-out }\end{array}$ \\
\hline $\begin{array}{l}\text { Brooks et al. } \\
\text { (1993) }\end{array}$ & $\begin{array}{l}\text { Ultrasonic cement removal device } \\
\text { (Ultradrive, Biomet Inc, Warsaw, IN) } \\
40 \mathrm{kHz} \\
40 \mathrm{\mu m} \text { p-p amplitude }\end{array}$ & $\begin{array}{l}\text { PMMA cement } \\
\text { removal }\end{array}$ & $\begin{array}{l}\text { Human femur, ex } \\
\text { vivo }\end{array}$ & - & $\begin{array}{l}\text { No adverse temperature elevation } \\
\text { when saline used } \\
\text { Microsoopy: conversion of bone } \\
\text { cement from an interlocked to } \\
\text { homogenous granular material }\end{array}$ \\
\hline $\begin{array}{l}\text { Brooks et al. } \\
\text { (1995) }\end{array}$ & $\begin{array}{l}\text { Ultrasonic cement removal device } \\
\text { (Ultradrive, Biomet Inc, Warsaw, IN) }\end{array}$ & $\begin{array}{l}\text { PMMA cement } \\
\text { removal }\end{array}$ & $\begin{array}{l}\text { Human femur with } \\
\text { prosthesis, ex vivo }\end{array}$ & $\begin{array}{l}\text { Average force } 25 \mathrm{~N} \text { required for cement } \\
\text { removal } \\
\text { Perforation does not occur with forces } \\
\text { used operatively, except for very thin } \\
\text { cortex ( } 1 \mathrm{~mm})\end{array}$ & No fracture or perforation observed \\
\hline $\begin{array}{l}\text { Goldberg et al. } \\
(2005)\end{array}$ & $\begin{array}{l}\text { Ultrasonic cement removal device } \\
\text { (OSCAR, Orthosonics Ltd, Upr } \\
\text { Montclair, N) } \\
28-29 \mathrm{kHz}\end{array}$ & $\begin{array}{l}\text { PMMA cement } \\
\text { removal }\end{array}$ & $\begin{array}{l}\text { Distal human } \\
\text { humerus, ex vivo }\end{array}$ & $\begin{array}{l}\text { Thermocouple measurement of } \\
\text { temperature elevation }\end{array}$ & Histology: thermal (radial nerve) injury \\
\hline
\end{tabular}

\subsubsection{Bone}

Intuitively, the mechanism of bone and hard tissue removal for cutting applications cannot be the same as that described by Cimino and Bond for soft tissue. It is more likely to be mechanical impact, shock waves in a fluid and perhaps, bone microfracture. No theory of interaction has been proven for the ultrasound-hard tissue interaction. Micro-fractures have not been reported when using ultrasound saws in bone cut ting, suggesting that this is unlikely to be the primary bone destruction mechanism (Aro et al., 1981). Smith et al. developed a model using FEA to better understand the fracture process for ultrasound cutting in a brittle material. Their model predicts that friable materials can be successfully cut by an ultrasonic cutting system based on a crack propagation mechanism (Smith et al., 1996). A practical application of this is that the most appropriate blade modal parameters can be predicted for cutting different types of material for improved efficiency and control.

\subsubsection{Cardiovascular}

Effects of ultrasonic ablation for vascular plaques and chronic total occlusion include cavitation and mechanical plaque disruption. In ultrasound angioplasty, direct mechanical contact between the oscillating tip and vascular plaque results in fragmentation and ablation of material into microscopic particles (Rosenschein et al., 1990). Flexible biological materials such as healthy arterial wall or skin easily distend with the oscillation of the distal-tip. In contrast, the rigid calcium plaque matrix lacks flexibility and is disrupted (Demer et al., 1991). Cimino and Bond (1996) 
provide further support for this mechanism in their failure to ablate aortic wall tissue using an experimental ultrasonic aspirator. They cite increased tissue strength, contributed to by higher concentrations of collagen and elastin, as the reason for a observing no tissue fragmentation under these conditions. They suggest that collagen type, quantity and organization each affect structural quality and are responsible for reduced fragmentation. They hypothesise that for aorta, the ultrasonic aspirator simply pounds on the tissue until thermal damage occurs or the tissue tears away. The authors additionally claim poor fragmentation in vessel structures, tendons, ligaments, healthy skin and organ capsules, but do not provide experimental evidence for these tissues.

\subsubsection{Bone cement}

A different mechanism is described for the ultrasound-bone cement interaction in orthopaedic revision arthroplasty. When the ultrasonic tip is pressed against polymethyl metacrylate (PMMA) cement, it creates friction at the tip cement interface and intermolecular friction within the cement mantle. The absorbed energy alters the structure and mechanical properties of the cement in contact with the surface of the working tool bit, softening it to a gum-like pliable consistency to facilitate accelerated cement removal (Klapper et al., 1992). Microscopic examination of cement demonstrates structural change in the bone cement converting it from a microscopically spherical interlocked material to a homogenous granular substance (Brooks et al., 1993). This process is analogous to insertion of metal screws into plastic parts during ultrasonic assembly (Walter, 1968). Power is increased automatically in response to increased tip pressure, maintaining the cement softening capacity of the instrument under varying manual load. Ultrasonic energy may alternatively be applied to a metal prosthesis securely fixed in cement by directly coupling the transducer to the prosthesis, where the energy transmitted is absorbed by the cement-metal interface. None of the removal mechanisms described is supported by a mathematical model. Mathematical models for human tissue are difficult to develop. Composition of water, colla gen and elastin vary between tissues, even of the same type, rendering it difficult to describe tissue with a simple function.

\subsection{Efficiency}

\subsubsection{Qualitative measurement of efficiency}

\subsubsection{Particle size distribution.}

Chan et al. (1986) have described by qualitative means a method of measuring particle size distribution of ox liver tissue debris in emulsion collected from an 
experimental motor-driven surgical device and compared it to that for a ultrasonic surgical aspirator. While this method provides a simple and intuitive means of assessing instrument efficacy, its use is subject to interobserver variation. What is required are quantitative means of readily assessing tissue removal efficacy to permit reproducible testing conditions and allow comparison between different instruments with similar operating parameters.

\subsubsection{Quantitative measurements of efficiency}

\subsubsection{Material removal rate.}

Quantification of efficiency of soft tissue removal was first described in experimental studies by Chan et al. (1986). They described removal in terms of rate per unit time using ox-tissue liver as the test material. Their method permits examination of the effects of varying independently frequency, amplitude of vibration and suction pressure on the rate of removal. The fragmentation rate is a time-averaged measurement and yields repeatable experimental data. They found that beyond a given tip acceleration amplitude (100 g), further increases in tissue removal rate do not occur. They noted that removal rate is more or less independent of tip vibration amplitude within a range $300 \square \mathrm{m}-1 \mathrm{~mm}$. They additionally noted that tissue fragmentation occurred without significant manually applied pressure, minimizing unwanted damage, pulling and distortion of adjacent tissue. This quantitative method has also been used by Cimino and Bond (1996). They identified distal-tip peak-topeak displacement and suction as the two most significant operating parameters affecting rate of tissue fragmentation. Experiments with porcine brain, heart, liver, kidney and aortic tissue conducted at $23 \mathrm{kHz}$ and $0.2 \mathrm{~mm}$ stroke correlated tissue compressive strength with resistance to tissue fragmentation. They found that tissue strength is the parameter that provides the best basis for understanding the tissue selective property. Both strength and Young's modulus predict a fragmentation order from low to high of aorta $(\square=1.34 \mathrm{MPa} \pm 12 \%$; $\mathrm{E}=$ $2.09 \pm 3 \%$ ), kidney $(\square=0.33 \mathrm{MPa} \pm 12 \% ; \mathrm{E}=1.53 \pm 4 \%$ ), liver $(\square=0.25 \mathrm{MPa} \pm 9 \%$; $\mathrm{E}=$ $1.69 \pm 13 \%$ ), heart $(\square=0.27 \mathrm{MPa} \pm 10 \%$; $E=1.86 \pm 16 \%$ ) and brain $(\square=0.01 \mathrm{MPa}$; $\mathrm{E}=$ $0.03 \mathrm{MPa}$ (estimate)). Corresponding fragmentation rates reported vary from $\mathrm{Omg} / \mathrm{s}$ (aorta) to $484 \mathrm{mg} / \mathrm{s}$ (brain). Fragmentation is shown to be independent of both tissue percentage water content and tissue density (Cimino and Bond, 1996). This provides further evidence that as collagen and elastin content of tissue increases, associated with increased strength, ultrasonic devices aspirate less efficiently.

\subsubsection{Force measurement.}

Khambay and Walmsley (2000a) designed an ultrasonic chisel for bone cutting based on adaptation of a commercially available ultrasonic dental scaler to study this difference. Their device used a modified straight ultrasonic end-effector shaped 
like a chisel that oscillated in a longitudinal manner at $30 \square \mathrm{m} \mathrm{p}-\mathrm{p}$ amplitude to produce a chiselling action to remove bone. They recorded a greater force applied by clinicians when using an ultrasonic chisel in a comparison study with a conventional air driven rotary bur. Efficiency was calculated as the product of rate and depth of cut for both instruments. The rotary bur cut bone faster and produced a deeper cut than the ultrasonic chisel. However, greater precision of cut was claimed for the ultrasonic chisel, but this requires further evaluation in clinical studies. In a separate experiment, Khambay and Walmsley (2000b) analysed factors that influence bone cutting by an ultrasonic chisel using a similar force measurement system. They concluded that optimum cutting occurs when the ultrasonic chisel is operated at low force and low cutting rate with the instrument held at a low rake angle (i.e. parallel to bone). However, their study did not experimentally assess precision of cut, volume of bone removed or damage caused to surrounding tissue. In particular, at faster cutting rates with greater impact forces, the potential for collateral damage in the bone is not known. This observation requires further experimental investigation.

\subsubsection{Power measurement.}

In a further paper, Cimino (2001) describes two simple acoustic power measures referred to as $\mathrm{H} 2 \mathrm{O}$ power and energy efficiency that can be together used to develop zones of optimal efficiency for ultrasonic instrumentation. Collectively these studies provide ex vivo qualitative and quantitative methods for assessment of efficacy of ultrasonic tissue ablation and cutting instruments. These measurements will assist in standardizing clinical assessment of instrument efficacy.

\subsubsection{Device safety}

IEC standards for safety of medical electro-equipment are established in the 60601 series. Part 1 is the primary standard that specifies safety criteria, and applies to all medical electroequipment and specifies safety criteria from thermal, electric and mechanical sources (IEC, 2005). It does not contain a specific statement concerning ultrasound. Although there are two particular, or part 2, safety standards in IEC 60601 concerning medical use of ultrasound, neither addresses surgical ultrasonic device safety. Neither does the European Union Medical Device Directive (MDD) establish limits for protection of operators from ultrasound emissions (European Communities, 1993).

\subsection{Tissue damage effects}

Patient safety and user confidence in ultrasonic instruments requires a detailed understanding of the effects of dissipated energy in residual tissue. Adverse effects in tissue adjacent to the intended site of ultrasonic instrument action have not been 
adequately defined for many clinical applications. Ultrasonic exposures are allowed which are sufficient to effect tissue removal and destruction. However, there are no specific internationally accepted defined standards to reduce harmful tissue effects.

\subsubsection{Global biomechanical properties}

Using a prototype intravascular ultrasound device, Fischell et al. (1991) report increased compliance due to arterial smooth muscle relaxation in an ex vivo study. This finding was supported by absence of thermal damage or smoothmuscle injury by scanning electron microscopy (SEM). In a separate study, Demer et al. (1991) observed increased arterial distensibility in an atherosclerotic human cadaveric study. This permitted selective disruption of rigid fibrous elements and calcium in the atherosclerotic arterialwall. Neither of these experimental studies reported evidence of vessel perforation. However, vessel perforation had been reported in an earlier study by Siegel et al. (1988). They found that perforation is avoidable with pulsed wave energy, keeping power below $50 \mathrm{~W}$ and duration less than $30 \mathrm{~s}$. In whole bone strength studies using an ex vivo canine model and torsion testing, Callaghan et al. (1992) found no decrease in ultimate torque, maximum angle and energy capacity after ultrasonic bone cement removal. In another study, Brooks et al. (1995) assessed the average load generated across cortical bone by ultrasonic tools while removing cement. In general, risk of cortical perforation for any cement extraction instrument increases as the thickness of femoral cortex decreases. The average load required to perforate a $2 \mathrm{~mm}$ cortex was $80 \mathrm{~N}$. They reported a relationship between the rate of application of load and the load at which perforation occurred. It is suggested that thismay be due to a damping effect that increasing rates of load application have on the oscillating tip or to the viscoelastic mechanical properties of cortical bone.

\subsubsection{Histomorphological}

Healing response in bone in vivo after ultrasound cutting has been assessed histologically by Horton et al. (1975). They observed that the rate of bone repair after cutting was slower for a conventional speed rotary bur in comparison with a standard surgical chisel or an ultrasonic instrument. In 1981, Aro et al. (1981) compared the immediate and long-term effects of an oscillating sawand an ultrasonic sawon rabbit scapula and tibia in vivo, by histology and by scanning electron microscopy. The ultrasonic saw produced rougher surfaces compared to the oscillating saw but did not induce micro-fracture. The regeneration process was found to be of the same duration by either method. Other disadvantages cited for the ultrasonic saw was that the apparatus was large and unwieldy and the instrument overheated during operation. Caillouette et al. provide evidence of bone viability in their study of an ultrasonic cement-removal tool in direct comparison with a high-speed burr. Histologically, they observed no micro-fractures 
or perforation, a reduced zone of osteonecrosis and new bone formation at 2 weeks post-operatively (Caillouette et al., 1991a).

\subsubsection{Protein denaturation/necrosis}

Electrosurgical devices cause a rapid rise in tissue temperature in excess of $300 \circ \mathrm{C}$, which produces thermal alterations such as carbonization, charring, and desiccation. In addition, energy from the device travels both laterally and axially into the surrounding tissue. Benefits of reduced thermal energy damage have been proven for high-power ultrasound over electrosurgical dissection (Kinoshita et al., 1999). However, the ablation and cutting process is associated with temperature elevation on the tip or blade surface resulting in denaturation of protein in tissue. For denaturation of proteins to occur, a minimum temperature elevation of $4 . \mathrm{C}$ is necessary. Denaturation and coagulation of the protein in sectioned tissue may be desirable in certain applications for closing vascular structures and haemostasis, supporting the cutting process (Amaral, 1994). For vascular applications, Siegel et al. (1988) have reported that risk of thermal damage is associated with use of continuous wave energy and vessel perforation. In an early stage of development, the temperature increase during the application of a scalpel-type ultrasonic surgical device was estimated using a thermocouple (Nowotny et al., 1989). Kadesky et al. (1997) reported that extensive tissue coagulation and trans-mural vessel necrosis occur when using an ultrasonically activated scalpel at standard operative settings. In this in vivo pig study, although significant histological damage occurred to bile duct and ureter, none of the dissected specimens demonstrated any macroscopic signs of injury, and energy dispersion observed was less than when using electrosurgery at comparable settings. Separately, Emam and Cuschieri (2003), using infrared heat tissue mapping in an in vivo pig model demonstrated elevation of temperature of greater than $60 \circ \mathrm{C}$ in an ultrasonic dissector shaft, cutting jaw and at distances up to $2.5 \mathrm{~cm}$ from the site of instrument action after activation for 10-15 s. Again, despite normal macroscopic appearance, histological analysis under light microscopy revealed extensive cellular injury in the zones of thermal damage. Collateral damage was absent or insignificant after dissection at reduced power levels and activation times not exceeding $5 \mathrm{~s}$. They concluded that heat production in an ultrasonic dissector is directly proportional to the power setting and activation time. They recommended that power level be reduced when dissecting near important structures. In a comparable study performed in a perfusion model, using the Harmonic Scalpel (Ultracision, Ethicon, Norderstedt, Germany), Koch et al. (2003) recorded temperature elevation in excess of $40 . \mathrm{C}$ at $1 \mathrm{~mm}$ distance from the blades, where as at distances of greater than $5 \mathrm{~mm}$, perfusion removed the heat efficiently, confirming the importance of perfusion in minimizing adverse effects. They concluded that chances of tissue damage are remote providing a safety margin of $3 \mathrm{~mm}$ is maintained from sensitive tissue structures. It is essential that similar defined operative safety margins are verified for other ultrasonic instruments. Ultrasonic saws are limited to small bones, or to the resection of pathological tissue, 
since the system's rate of cutting are low. In experimental studies, Grasshoff and Beckert (1981) report ultrasound-induced temperature elevation several degrees higher than temperatures obtained by cutting with conventional saws. However, in contrast to work by Aro et al. (1981), temperature elevation is not reported to have had any adverse histological effect in tissue in their study.

PMMA bone cement has a high capacity for energy absorption and a low thermal conductivity (Schultz, 1977). This provides relative protection for surrounding bone and tissues from substantial temperature increase. In clinical studies, a reduced incidence of thermal damage is reported with the use of ultrasonic instruments in comparison with alternative bone cement-removal techniques (Gardiner et al., 1993; Klapper et al., 1992). In human cadaver bone studies, Caillouette et al. and Brooks et al. report temperature generation at the bone-cement interface of $39 \circ \mathrm{C}$ and $80 \circ \mathrm{C}$, respectively (Brooks et al., 1993; Caillouette et al., 1991b). This is less than that generated by high speed drills (140 ${ }^{\circ} \mathrm{C}$ ) (Matthews and Hirsch, 1972). It had previously been demonstrated that the threshold for bone viability is a temperature of greater than $47 \circ \mathrm{C}$ for a duration of $1 \mathrm{~min}$ or more (Eriksson and Albrektsson, 1983). They concluded that bone remains viable providing ultrasound tools are used in conjunction with irrigation, as temperatures produced at the bone-cement interface were below $47{ }^{\circ} \mathrm{C}$ at $1 \mathrm{~min}$ in their study. Goldberg et al. (2005) report a case of muscle necrosis, radial nerve palsy and humeral fracture developing secondary to thermal damage in a revision total elbow arthroplasty. The findings from this study suggest that heat can potentially be transmitted from within the humeral canal directly to the nerve because of its close proximity. To eliminate thermal damage, intermittent delivery of energy and use of cold irrigation between probe passes is advocated. Effects of cutting blade parameters and cutting geometry on cutting temperatures in bone have been studied by Cardoni et al. using ultrasonic probes operating at 35 and $19.5 \mathrm{kHz}$. Their aim was to design an ultrasonic cutting device capable of producing deep cuts in bone without the need for incorporation of a cooling system (Cardoni et al., 2006). They show that thermal generation is dependent on cutting blade velocity, applied load, frequency and blade specimen coupling contact. They found that thermal damage in tissue could be reduced or eliminated through judicious control of cutting blade parameters designed to reduce contact area between the blade and specimen. Current understanding of potential for damage to surrounding structures relative to intraoperative settings has permitted optimization of cooling for ultrasonic dissectors. However, a safety margin for the operation of many contemporary instruments has not been defined. Sources of thermal injury can potentially be controlled with appropriate surgical technique and appropriate system design. System design should incorporate adequate irrigation (Goldberg et al., 2005; Brooks et al., 1993) or wetting solution (Cooter et al., 2001) and limitation of tissue contact time (Emam and Cuschieri, 2003), as well as reduction in cutting blade velocity, load (Cardoni et al. , 2006) and p-p tip amplitude (Chan et al., 1986). 


\subsubsection{Cellular}

At a cellular level, ultrasound causes osteoblast loss of viability in vitro, both when adherent to a substrate and in suspension. Sura et al. (2001) have shown experimentally that loss of viability is directly related to maximum displacement of the ultrasonic tip for an ultrasonic bone cutting instrument. 


\section{Future research direction}

Cavitation, direct mechanical and thermal effects occur simultaneously in the presence of high power, low-frequency ultrasound. For successful tissue cutting or ablation, the interaction of these effects with the local tissue structures must be well understood and controlled to avoid excessive residual damage. Known advantages of ultrasonic systems such as increased precision of cut and reduced cutting forces, in comparison with traditional cutting and dissection methods, will drive ongoing development of future ultrasonic instruments. The medical practitioner requires a clearer understanding of critical instrument performance variables under his/her direct control that will affect surgical outcome and a means by which to correlate favourable or unfavourable results with the selectionmade.Asimple, intuitive, and scientifically based system is therefore needed to compare the efficacy of different ultrasonic surgical instruments. Further evaluation of ultrasound tissue effects ex vivo and in vivo should target definition of damage and removal mechanisms. The cavitation, thermal and direct mechanical removal and damage effects are not yet adequately understood, either from the point of view of device performance or the effects on residual tissue. This review highlights a number of areas where deficits in current understanding need to be addressed.

\subsection{Cavitation}

Threshold conditions for the onset of cavitation in various hydrated tissues require more precise definition, preferably mathematical models underpinned by an extensive body of experimental evidence. The conditions associated with the onset of associated necrosis and morphological damage also merit a more precise description.

\subsection{Thermal}

Ultrasonic instruments also have the potential to elicit damage by necrosis and protein denaturation via a thermal mechanism. The dissipation of ultrasonic and thermal energy in local tissues is an important issue in this respect, and is key to building a reliable predictive model of this phenomenon.

\subsection{Direct mechanical}

A more detailed evaluation of the probe-tissue-fluid interaction is required. This is particularly pertinent in the case of hard tissues such as bone, where the removal mechanism has not been adequately described. It is unlikely that ultrasound cuts or fragments by the direct contact ablation mechanism described for soft tissues. In soft tissues, the precise failure mechanisms for the various multi-constituent hydrated tissues are not yet clearly described. Therefore, the role of micro fracture in hard 
tissues and the mechanism of non-thermal damage in soft tissue deserve a more thorough experimental investigation.

\section{Acknowledgement}

Authors would like to acknowledge funding provided by Enterprise Ireland.

\section{References}

Ali, M.I., Butman, S., Heuser, R., 2006. Crossing a chronic total occlusion using combination therapy with Tornus and FlowCardia. J. Invasive Cardiol. 18, E258-E260.

Amaral, J.F., 1994. The experimental development of an ultrasonically activated scalpel for laparoscopic use. Surg. Laparosc. Endosc. 4, 92-99.

Amso, N.N., 1994. Applications of therapeutic ultrasound in medicine. Ultrasonics Sonochem. 1, S69-S71.

Anis, A.Y., 1999. PhacoTmesis. In: Masket, S., Crandall, A.S. (Eds.), Atlas of Cataract Surgery. Martin Dunitz Ltd., London, pp. 89-96.

Anschuetz, R., Bernard, H.R., 1965. Ultrasonic irradiation and atherosclerosis. Surgery 57, 549-553.

Ariani, M., Fishbein, M.C., Chae, J.S., Sadeghi, H., Michael, A.D., Dubin, S.B., Siegel, R.J., 1991. Dissolution of peripheral arterial thrombi by ultrasound. Circulation 84, $1680-1688$.

Aro, H., Kallioniemi, H., Aho, A.J., Kellokumpu-Lehtinen, P., 1981. Ultrasonic device in bone cutting. A histological and scanning electron microscopical study. Acta. Orthop. Scand. 52, 5-10.

Atar, S., Luo, H., Nagai, T., Siegel, R.J., 1999. Ultrasonic thrombolysis: catheterdelivered and transcutaneous applications. Eur. J. Ultrasound 9, 39-54.

Balamuth, L., 1963. Ultrasonically Vibrated Cutting Knives. US Patent 3086288.

Balamuth, L., 1963b. Ultrasonics and dentistry. Sound 2, 15-19.

Balamuth, L., 1970. Removing Tissue from a Biological Organism. US Patent 3526219.

Barnett, S.B., Rott, H.D., ter Haar, G.R., Ziskin, M.C., Maeda, K., 1997. The sensitivity of biological tissue to ultrasound. Ultrasound Med. Biol. 23, 805-812.

Beissner, K., 1980. An Investigation of the Sound Field of the Opthalmo-surgical Ultrasonic Equipment. Verlag VDE, Association of German Electro-Engineers, Berlin.

Bond, L.J., Cimino, W.W., 1996. Physics of ultrasonic surgery using tissue fragmentation. Part II. Ultrasound Med. Biol. 22, 101-117.

Brooks, A.T., Nelson, C.L., Stewart, C.L., Skinner, R.A., Siems, M.L., 1993. Effect of an ultrasonic device on temperatures generated in bone and on bone-cement structure. J. Arthroplasty 8, 413-418. 
Brooks, A.T., Nelson, C.L., Hofmann, O.E., 1995. Minimal femoral cortical thickness necessary to prevent perforation by ultrasonic tools in joint revision surgery. J. Arthroplasty 10, 359-362.

Brujan, E.A., 2004. The role of cavitation microjets in the therapeutic applications of ultrasound. Ultrasound Med. Biol. 30, 381-387.

Brujan, E.A., Nahen, K., Schmidt, P., Vogel, A., 2001a. Dynamics of laser-induced cavitation bubbles near an elastic boundary. J. Fluid Mech. 433, 251-281.

Brujan, E.A., Nahen, K., Schmidt, P., Vogel, A., 2001b. Dynamics of laser-induced cavitation bubbles near elastic boundaries: influence of the elastic modulus. J. Fluid Mech. 433, 283-314.

Burstein, G., Yoon, P., Saleh, K.J., 2004. Component removal in revision total hip arthroplasty. Clin. Orthop. Relat. Res. , 48-54.

Caillouette, J.T., Gorab, R.S., Klapper, R.C., Anzel, S.H., 1991a. Revision arthroplasty facilitated by ultrasonic tool cement removal. Part II. Histologic analysis of endosteal bone after cement removal. Orthop. Rev. 20, 435-440.

Caillouette, J.T., Gorab, R.S., Klapper, R.C., Anzel, S.H., 1991b. Revision arthroplasty facilitated by ultrasonic tool cement removal. Part I. In vitro evaluation. Orthop. Rev. $20,353-357$.

Callaghan, J.J., Elder, S.H., Stranne, S.K., Fulghum, C.F., Seaber, A.V., Myers, B.S., 1992. Revision arthroplasty facilitated by ultrasonic tool cement removal. An evaluation of whole bone strength in a canine model. J. Arthroplasty 7, 495-500.

Campbell, B., Maddern, G., 2003. Safety and efficacy of interventional procedures. Br. Med. J. 326, 347-348.

Cardoni, A., Lucas, M., Cartmell, M., Lim, F., 2004. A novel multiple blade ultrasonic cutting device. Ultrasonics 42, 69-74.

Cardoni, A., MacBeath, A., Lucas, M., 2006. Methods for reducing cutting temperature in ultrasonic cutting of bone. Ultrasonics 44, e37-e42.

Chan, K.K., Watmough, D.J., Hope, D.T., Moir, K., 1986. A new motor-driven surgical probe and its in vitro comparison with the cavitron ultrasonic surgical aspirator. Ultrasound Med. Biol. 12, 279-283.

Cimino, W.W., 1999. The physics of soft tissue fragmentation using ultrasonic frequency vibration of metal probes. Clin. Plast. Surg. 26, 447-461.

Cimino, W.W., 2001. Ultrasonic surgery: power quantification and efficiency optimization. Aesthetic Surg. J. 21, 233-241.

Cimino, W.W., Bond, L.J., 1996. Physics of ultrasonic surgery using tissue fragmentation. Part I. Ultrasound Med. Biol. 22, 89-100.

Conte, E., Delorenzi, E., 1940. Azzoni biologische delgi ultrasuoni. Atti. Congr. Radiobiol. 4, 195-204. 
Cooter, R., Babidge, W., Mutimer, K., Wickham, P., Robinson, D., Kiroff, G., Chapman, A., Maddern, G., 2001. Ultrasound-assisted lipoplasty. ANZ J. Surg. 71, 309-317.

Demer, L.L., Ariani, M., Siegel, R.J., 1991. High intensity ultrasound increases distensibility of calcific atherosclerotic arteries. J. Am. Coll. Cardiol. 18, 1259-1262.

Duck, F.A., 2007. Medical and non-medical protection standards for ultrasound and infrasound. Prog. Biophys. Mol. Biol. 93, 176-191.

Edler, I., 1989. Echocardiography, a historical perspective. In: Schapira, J.N., Harold, J.G. (Eds.), Two-dimensional Echocardiography and Cardiac Doppler. Williams and Wilkins, Baltimore, pp. 1-33.

Egemen, N., 1992. Suction control attachment for ultrasonic aspirators, Technical note. J. Neurosurg. 77, 316-317.

Eggers, G., Klein, J., Blank, J., Hassfeld, S., 2004. Piezosurgery: an ultrasound device for cutting bone and its use and limitations in maxillofacial surgery. Br. J. Oral Maxillofac. Surg. 42, 451-453.

Emam, T.A., Cuschieri, A., 2003. How safe is high-power ultrasonic dissection. Ann. Surg. 237, 186191.

Eriksson, A.R., Albrektsson, T., 1983. Temperature threshold levels for heat-induced bone tissue injury: a vital-microscopic study in the rabbit. J. Prosthet. Dent. 50, 101107.

European Communities, 1993. Council Directive 2003/10/EC of February 15, 2003. Minimum Health and Safety Requirements regarding Exposure of Workers to the Risks arising from Physical Agents (noise).

FDA, 1997. Guide for Preparing Product Reports for Medical Ultrasound Products. Centre for Devices and Radiological Health, US Department of Health and Human Services: Food and Drug Administration. FDA, 2007. The CROSSER Catheter, Model CR1 100 and System Electronics, Model Flowcardia Inc. 510(k), 510(k)s Final Decisions rendered for January 2007.

Fischell, T.A., Abbas, M.A., Grant, G.W., Siegel, R.J., 1991. Ultrasonic energy. Effects on vascular function and integrity. Circulation 84, 1783-1795.

Flamm, E.S., Ransohoff, J., Wuchinich, D., Broadwin, A., 1978. Preliminary experience with ultrasonic aspiration in neurosurgery. Neurosurgery 2, 240-245.

Fong, S.W., Klaseboer, E., Turangan, C.K., Khoo, B.C., Hung, K.C., 2006. Numerical analysis of a gas bubble near bio-materials in an ultrasound field. Ultrasound Med. Biol. 32, 925-942.

Gardiner, R., Hozack, W.J., Nelson, C., Keating, E.M., 1993. Revision total hip arthroplasty using ultrasonically driven tools. A clinical evaluation. J. Arthroplasty 8 , 517-521.

Gavin, G.P., McGuinness, G.B., Dolan, F., Hashmi, M.S.J., 2007. Performance characteristics of a therapeutic ultrasound wire waveguide apparatus, I. J. Mech. Sci. 49, 298-305. 
Goldberg, S.H., Cohen, M.S., Young, M., Bradnock, B., 2005. Thermal tissue damage caused by ultrasonic cement removal from the humerus. J. Bone. Joint. Surg. Am. 87, 583-591.

Goldman, D.E., Hueter, T.F., 1956. Tabular data of the velocity and absorption of high-frequency sound in mammalian tissues. J. Acoust. Soc. Am. 28, 35-37.

Goss, S.A., Frizzell, L.A., Dunn, F., 1979. Ultrasonic absorption and attenuation in mammalian tissues. Ultrasound Med. Biol. 5, 181-186.

Grasshoff, H., Beckert, M., 1981. Osteotomy with ultrasonics. Beitr. Orthop. Traumatol. 28, 299-305.

Grube, E., Sutsch, G., Lim, V.Y., Buellesfeld, L., lakovou, I., Vitrella, G., Colombo, A., 2006. High-frequency mechanical vibration to recanalize chronic total occlusions after failure to cross with conventional guidewires. J. Invasive Cardiol. 18, 85-91.

Hoigne, D.J., Stubinger, S., Von Kaenel, O., Shamdasani, S., Hasenboehler, P., 2006. Piezoelectric osteotomy in hand surgery: first experiences with a new technique. BMC Musculoskelet. Disord. 7, 36.

Horton, J.E., Tarpley Jr., T.M., Wood, L.D., 1975. The healing of surgical defects in alveolar bone produced with ultrasonic instrumentation, chisel, and rotary bur. Oral Surg. Oral Med. Oral Pathol. 39, 536-546.

Humphrey, J.D. , 2003. Continuum biomechanics of soft biological tissues. Proc. Royal Society, London, A 459, 3-46.

IEC, 2005. IEC 60601 Part I: Medical Electrical Equipment: General Requirements for Safety and Essential Performance. International Electrotechnical Commission, Geneva.

Inoue, T., Ikezaki, K., Sato, Y., 2000. Ultrasonic surgical system (SONOPET) for microsurgical removal of brain tumors. Neurol. Res. 22, 490-494.

Isomura, T., Suma, H., Sato, T., Horii, T., 1998. Use of the harmonic scalpel for harvesting arterial conduits in coronary artery bypass. Eur. J. Cardiothorac. Surg. 14, 101-103.

Kadesky, K.M., Schopf, B., Magee, J.F., Blair, G.K., 1997. Proximity injury by the ultrasonically activated scalpel during dissection. J. Pediatr. Surg. 32, 878-879.

Kelman, C.D., 1967. Pha/co-emulsification and aspiration. A new technique of cataract removal. A preliminary report. Am. J. Ophthalmol. 64, 23-35.

Kelman, C.D., 1973. Phaco-emulsification and aspiration: 500 cases. Am. J. Ophthalmol. 75, 764-768.

Khambay, B.S., Walmsley, A.D., 2000a. Investigations into the use of an ultrasonic chisel to cut bone. Part 1. Forces applied by clinicians. J. Dent. 28, 31-37.

Khambay, B.S., Walmsley, A.D., 2000b. Investigations into the use of an ultrasonic chisel to cut bone. Part 2. Cutting ability. J. Dent. 28, 39-44. 
Kim, K., Isu, T., Matsumoto, R., Isobe, M., Kogure, K., 2006. Surgical pitfalls of an ultrasonic bone curette (SONOPET) in spinal surgery. Neurosurgery 59, ONS390ONS393.

Kinoshita, T., Kanehira, E., Omura, K., Kawakami, K., Watanabe, Y., 1999. Experimental study on heat production by a $23.5-\mathrm{kHz}$ ultrasonically activated device for endoscopic surgery. Surg. Endosc. 13, 621-625.

Klapper, R.C., Caillouette, J.T., Callaghan, J.J., Hozack, W.J., 1992. Ultrasonic technology in revision joint arthroplasty. Clin. Orthop. Relat. Res., 147-154.

Kloehn, R.A., 1997. Commentary on ultrasound-assisted lipoplasty: task force July 1996 report to the membership. Plast. Reconstr. Surg. 99, 1198-1199.

Koch, C., Friedrich, T., Metternich, F., Tannapfel, A., Reimann, H.P., Eichfeld, U., 2003. Determination of temperature elevation in tissue during the application of the harmonic scalpel. Ultrasound Med. Biol. 29, 301-309.

Langevin, M.P., Ishimoto, M., 1923. Utilization des phenomen`es piezoelectrique pour la measure de l'intensit ‘e des sons en valeur absolute. J. Physiol. 4, 539-540.

Levy, M.L., McComb, J.G., 1999. Integration of a variable action suction adapter into ultrasonic aspirators. Neurosurgery 45, 893-895.

Lin, S.Y., 2004. Effect of electric load impedances on the performance of sandwich piezoelectric scalpels. IEEE Trans. Ultrason. Ferroelec. Freq. Contr. 51, 1280-1286.

Lin, S.Y., 2005. Load characteristics of high power sandwich piezoelectric ultrasonic transducers. Ultrasonics 43, 365-373.

Lucas, M., Graham, G., Smith, A.C., 1996. Enhanced vibration control of an ultrasonic cutting process. Ultrasonics 34, 205-211.

Lucas, M., Petzing, J.N., Cardoni, A., Smith, L.J., 2001. Design and characterisation of ultrasonic cutting tools. CIRP Annals 50, 149-152.

Lucas, M., MacBeath, A., McCulloch, E., Cardoni, A. , 2006. A finite element model for ultrasonic cutting. Ultrasonics 44, e503-e509.

Makin, R.S., Everbach, E.C., 1996. Measurement of pressure and assessment of cavitation for a $22.5 \mathrm{kHz}$ intra-arterial angioplasty device. J. Acoust. Soc. Am. 100, 1855-1864.

Matthews, L.S., Hirsch, C., 1972. Temperatures measured in human cortical bone when drilling. J. Bone. Joint Surg. Am. 54, 297-308.

Melzi, G., Cosgrave, J., Biondi-Zoccai, G.L., Airoldi, F., Michev, I., Chieffo, A., Sangiorgi, G.M., Montorfano, M., Carlino, M., Colombo, A., 2006. A novel approach to chronic total

occlusions: the crosser system. Catheter Cardiovasc. Interv. 68, 29-35.

Moreland, M.A., 1984. Ultrasonic impact grinding: what is it: what will it do. In: Proc. 22nd Abrasive Eng. Soc. Conf: Abrasives and Hi-technology, A 2-Way Street. pp. $111-117$. 
Nakase, H., Matsuda, R., Shin, Y., Park, Y.S., Sakaki, T., 2006. The use of ultrasonic bone curettes in spinal surgery. Acta Neurochir. (Wien) 148, 207-212, discussion 212-203.

NCRP, 1983. Biological Effects of Ultrasound: Mechanisms and Clinical Implications, Report 74. National Council on Radiation Protection and Measurements, NCRP, Bethesda, MD.

Neppiras, E.A., 1956. Report on ultrasonic machining. Metalwork Prod. 100, 12831604

Nishimura, G., 1954. Ultrasonic machining. Part I. J. Fac. Eng. Tokyo Univ. 24, 65-100.

Nowotny, K., Fritzsch, G., Fussel, J., Vetter, J., Wehner, W., Ludwig, P., Kuhnert, R., Morgenstern, R., Daniel, P., 1989. Tierexperimentelle Untersuchungen zur Leistungsultraschallchirurgie am Schweinepankreas. Z. Exp. Chir. Transplant Kunstliche. Organe. 22, 340-370.

Nyborg, W., 1996. Basic physics of low frequency therapeutic ultrasound. In: Siegel, R.J. (Ed.), Ultrasound Angioplasty (Developments in Cardiovascular Medicine). Kluwer Academic Publishers, Boston, pp. 1-23.

Perkins, J.P., 1986. Power ultrasonic equipment: practice and application. In: Based on a paper presented at the Sonochemistry Symposium, Annual Chemical Congress, Warwick University, UK.

Polyakov, V.A., 1972. Ultrasonic cutting and welding in clinical surgery. Sov. Med. 35, 29-34. Rawson, F.H., Morris, P.S., 1993. Ultrasonic Cutting Apparatus. US Patent 5226 343.

Reilly, G.A., McCormack, B.A., Taylor, D., 2004. Cutting sharpness measurement: a critical review. J. Mater. Proc. Technol. 153, 261-267.

Rosenschein, U., Bernstein, J., Di Segni, E., Kaplinsky, E., Bernheim, J., Rozenzsajn, L.A., 1990. Experimental ultrasonic angioplasty: disruption of atherosclerotic plaques and thrombi in vitro and arterial recanalisation in vivo. J. Am. Coll. Cardiol. 15, 711-717.

Rosenschein, U., Rozenzsajn, L.A., Kraus, L., Marboe, C.C., Watkins, J.F., Rose, E.A., David, D., Cannon, P.J., Weinstein, J.S., 1991. Ultrasonic angioplasty in totally occluded peripheral arteries. Initial clinical, histological, and angiographic results. Circulation 83, 1976-1986.

Scheflan, M., Tazi, H., 1996. Ultrasonically assisted body contouring. Aesthetic Surg. Q. $16,117-122$.

Schultz, J.M., 1977. Treatise on Materials Science and Technology, vol. 10, Properties of Solid Polymeric Materials. Part A. Academic Press, New York.

Seibel, B.S., 1993. Phacodynamics. Thorofare, Slack, NJ. Siegel, R.J., Fishbein, M.C., Forrester, J., Moore, K., DeCastro, E., Daykhovsky, L., DonMichael, T.A., 1988. Ultrasonic plaque ablation. A new method for recanalization of partially or totally occluded arteries. Circulation 78, 1443-1448.

Siegel, R.J., Gunn, J., Ahsan, A., Fishbein, M.C., Bowes, R.J., Oakley, D., Wales, C., Steffen, W., Campbell, S., Nita, H., et al., 1994. Use of therapeutic ultrasound in 
percutaneous coronary angioplasty. Experimental in vitro studies and initial clinical experience. Circulation 89, 1587-1592.

Singh, R., Khamba, J.S., 2006. Ultrasonic machining of titanium and its alloys: a review. J. Mater. Proc. Technol. 173, 125-135.

Smith, A., Nurse, A., Graham, G., Lucas, M., 1996. Ultrasonic cutting-a fracture mechanics model. Ultrasonics 34, 197-203.

Sobbe, A., Stumpff, U., Trubestein, G., Figge, H., Kozuschek, W., 1974. Die ultraschallauflosung von thromben. Klin. Wochenschr. 52, 1117-1121.

Stumpff, U., Pohlman, R., Trubestein, G., 1975. A new method to cure thrombi by ultrasonic cavitation. Ultrasonics Int. Conf. Proc., 273-275.

Sundt, T.M.J., Piepgras, D.G., Stevens, L.N., 1991. Surgery for supratentorial arteriovenous malformations. Clin. Neurosurg. 37, 49-115.

Sura, H., Shelton, R.M., Walmsley, A.D., 2001. Osteoblast viability and detachment following exposure to ultrasound in vitro. J. Mater. Sci. Mater. Med. 12, 997-1000.

Thoe, T.B., Aspinwall, D.K., Wise, M.L.H., 1998. Review on ultrasonic machining. Int. J. Mach. Tools Manufact. 38, 239-255.

Topaz, M., 1998. Long-term possible hazardous effects of ultrasonically assisted lipoplasty. Plast. Reconstr. Surg. 102, 280, author reply 280-281.

Vang, A., 1955. Vibratory Surgical Instruments. US Patent 2714890.

Vercellotti, T., 2004. Technological characteristics and clinical indications of piezoelectric bone surgery. Minerva Stomatol. 53, 207-214.

Vercellotti, T., De Paoli, S., Nevins, M., 2001. The piezoelectric bony window osteotomy and sinus membrane elevation: introduction of a new technique for simplification of the sinus augmentation procedure. Int. J. Periodontics Restorative Dent. 21, 561-567.

Volkov, M.V., Shepeleva, I.S., 1974. The use of ultrasonic instrumentation for the transection and uniting of bone tissue in orthopaedic surgery. Reconstr. Surg. Traumatol. 14, 147-152.

Walmsley, A.D., 1988. Applications of ultrasound in dentistry. Ultrasound Med. Biol. 14, 7-14.

Walmsley, A.D., Laird, W.R., Williams, A.R., 1984. A model system to demonstrate the role of cavitational activity in ultrasonic scaling. J. Dent. Res. 63, 1162-1165. Walmsley, A.D., Laird, W.R., Lumley, P.J., 1992. Ultrasound in dentistry. Part 2. Periodontology and endodontics. J. Dent. 20, 11-17.

Walter, R., 1968. Ultrasonic assembly of thermoplastics. Mod. Plastics Encyclopedia 45. Weisz, G., Moses, J.W., 2007. New percutaneous approaches for chronic total occlusion of coronary arteries. Expert Rev. Cardiovasc. Ther. 5, 231-241.

Wells, P.N.T., 1984. Medical ultrasonics. IEEE Proc. A 131, 225-232. 
Wiksell, H., Martin, H., Coakham, H., Berggren, A., Westermark, S., 2000. Miniaturised ultrasonic aspiration handpiece for increased applicability. Eur. J. Ultrasound 11, 4146. Wood, R.W., Loomis, A.L., 1927. The physical and biological effects of high frequency sound waves of great intensity. Philosoph. Mag. J. Sci. 4, 417-436.

Wuchinich, D.G., Broadwin, A., Anderson, R.P., 1977. Ultrasonic Aspirator. US Patent 4 063557.

Ying, C., Zhaoying, Z., Ganghua, Z., 2006. Effects of different tissue loads on high power ultrasonic surgery scalpel. Ultrasound Med. Biol. 32, 415-420.

Zocchi, M., 1992. Ultrasonic liposculpturing. Aesthetic Plast. Surg. 16, 287-298. 